\title{
Diet, Mobility, Technology, and Lithics: Neolithization on the Andean Altiplano, 7.0-3.5 ka
}

\author{
Nathaniel Kitchel ${ }^{1}$ (D) $\cdot$ Mark S. Aldenderfer $^{2}$ (D) Randall Haas $^{3}$ (D)
}

Accepted: 15 April 2021/Published online: 4 May 2021

(C) The Author(s) 2021

\begin{abstract}
Neolithization was a complex, protracted process of domestication, sedentarization, and technology change that occurred in various combinations in various times and places around the world. Understanding the causal relationships among those and other important human behaviors remains an analytical challenge. This study examines Neolithization through the lens of lithic artifact variation in the Lake Titicaca Basin, Peru. Drawing on previous lithics research, we outline a synthetic model linking changing diet, mobility, and projectile technology to predicted trends in lithic assemblages. The expectations are then compared to two large, well-dated lithic assemblages from the Titicaca Basin - one from the Middle/Late Archaic forager site of Soro Mik'aya Patjxa (8.0-6.5 cal. ka) and the other from the Terminal Archaic horticultural site of Jiskairumoko (5.2-3.4 cal. ka). We find that the strongest signal in lithic technology change is related to the introduction of archery technology. Signals for subsistence change and declining mobility are relatively weak. The results suggest an early but unconfirmed adoption of archery technology in the Terminal Archaic Period with major transitions in mobility and diet likely to have occurred subsequently in the Terminal Archaic or Formative periods. The findings are consistent with a behavioral model in which changes in projectile technology played a prominent role in the evolution of resource intensification and residential sedentism as well as resource privatization and sexual division of labor in the high Andes.
\end{abstract}

Keywords Hunter-gatherer · Neolithization · Lithics · Andes

Randall Haas

wrhaas@ucdavis.edu

1 Dartmouth College, Hanover, NH, USA

2 University of California, Merced, CA, USA

3 University of California, Davis, CA, USA 


\section{Introduction}

A number of forager societies around the world independently experienced a protracted, meta-stable period of economic transformation from foraging to food production and residential mobility to sedentism often accompanied by emergent archery and ceramic technologies (Kelly, 2013; Smith, 2001; Stiner, 2001). Understanding the causal relationships among these and other behaviors presents a major analytical challenge for archaeologists. At first blush, it would seem reasonable to suppose any combination of linear or non-linear causal chains among these behaviors. For example, it seems reasonable to suggest that sedentism, perhaps due to population packing and territoriality, drove resource domestication and technology change (Rosenberg, 1998). But it would also seem reasonable to reverse the causal arrow to suggest that domestication or technology change drove emergent sedentism (Bettinger, 2015; Richerson et al., 2001). To complicate matters further, we could imagine that any combination of the three behaviors incrementally fed back on one another and thus coevolved in tandem. The extent to which a given model applies to a given archaeological case may be evaluated empirically with careful comparison and relative dating of material correlates of the respective behaviors. By characterizing the tempo and order in which these behaviors emerged, it may be possible to understand causal relationships among them and other important human behaviors such as resource privatization, territoriality, sexual division of labor, and hierarchy.

One of the world's major geographic loci of endogenous "Neolithization," and the focus of our analysis, is the Lake Titicaca Basin in the Andean Altiplano, or High Plains, of South America (Janusek, 2004; Stanish, 2003). The first six millennia of Titicaca Basin occupation are characterized as a protracted period of foraging lifeways that includes the Early-Late Archaic periods, 11-5.0 cal. ka (Aldenderfer, 1989; Aldenderfer \& Flores Blanco, 2011; Klink \& Aldenderfer, 2005). Pedestrian survey and limited excavation offer preliminary insights into socioeconomic organization at that time. Large projectile points are frequent, indicative of large mammal hunting, likely with atlatl technology (Cipolla, 2005; Craig, 2011; Haas et al., 2015; Klink, 2005). Among the hundreds of recorded Late Archaic sites, neither surface architecture nor earth moving activities have been observed suggesting a high degree of residential mobility (Cipolla, 2005; Klink, 2005).

Excavations and ground-penetrating radar conducted at the large Late Archaic site of Pirco did not find archaeologically detectable architecture (Craig, 2012). Ceramic technology has not been observed in limited excavations at Soro Mik'aya Patjxa (Haas \& Viviano Llave, 2015), further suggesting a high degree of residential mobility. However, human bone isotope chemistry indicates that annual rounds were restricted to the highlands, at least in the Middle and Late Archaic periods (Haas et al., 2017). Abundant faunal remains at one site confirm the importance of big game (Haas \& Viviano Llave, 2015), but dental wear patterns and paleobotanical remains reveal that tubers likely played an important role in these early subsistence economies (Haas \& Viviano Llave, 2015; Watson \& Haas, 2017). The sum of Late Archaic Period evidence therefore suggests a relatively mobile highland forager population with a mixed terrestrial subsistence economy reliant on atlatl technology.

The subsequent Terminal Archaic Period, 5.0-3.5 cal. ka, marks the beginning of dramatic socioeconomic change relative to the preceding 6000 years. Ceramic 
technology, semi-subterranean houses, and the first earth works in the form of small burial mounds all appear during the Terminal Archaic Period, suggesting an increase in residential sedentism and territoriality at that time (Craig, 2011; Craig, 2012). Starch grains from cultivated or domesticated potatoes and thin-testa Chenopodium seeds have been recovered from Terminal Archaic Period contexts, indicating that incipient agricultural economies were beginning to emerge (Bruno, 2006; Rumold \& Aldenderfer, 2016). Hunting evidently continued to play an important role as evidenced by high frequencies of projectile points, but smaller projectile point forms suggest adoption of bow-and-arrow technology (Klink \& Aldenderfer, 2005; 52-54).

Societies also appear to have taken newfound interest in prestige. The earliest evidence of gold in the Americas is from the Terminal Archaic Period, and obsidian took on new prominence in the Terminal Archaic Period (Aldenderfer et al., 2008; Craig, 2012). Thus, the Terminal Archaic Period appears to have been marked by incipient sedentism, food production, and inequality with possible bow-and-arrow introduction.

While many aspects of socioeconomic change across the Late/Terminal Archaic boundary are readily apparent, many remain unclear. Botanical, ceramic, and architectural evidence would seem to indicate a degree of sedentarization. However, it is well known that horticultural societies tend to maintain high degrees of residential mobility (Kelly, 2013). While early ceramics are present at Jiskairumoko, they are relatively infrequent (Craig, 2012). Moreover, although ceramic technology tends to correspond to residential sedentism, there are wellknown exceptions (Eerkens, 2003). And although semi-subterranean houses are known from the Terminal Archaic Period, the house forms of earlier periods remain relatively unknown due to problems of preservation and limited research (Haas \& Viviano Llave, 2015). Only a single Late Archaic semi-subterranean house is known from the site of Jiskairumoko, but radiocarbon dates indicate that the feature dates to the end of the Late Archaic Period and possibly the beginning of the Terminal Archaic Period (Craig, 2012).

Similarly, the extent to which the subsistence economy changed between the Late and Terminal Archaic boundary remains unclear. While potato starch grains and thintesta quinoa have been identified in Terminal Archaic assemblages, comparable analyses have yet to be conducted for Late Archaic Period assemblages, hampering our ability to firmly place a start date on plant cultivation. Moreover, the continued prominence of projectile points in the Terminal Archaic would seem to suggest continued importance of hunting across the cultural transition, and the previously mentioned dental study indicates that tubers - presumably wild types - played a prominent role in Late Archaic Period economies. Such observations further erode the clarity of economic changes occurring between the Late and Terminal Archaic periods.

The adoption of archery technology in the Titicaca Basin Terminal Archaic Period also remains speculative, currently based on qualitative perceptions of a decrease in projectile point size. Owen's (1998) review of the evidence from the South Central Andean coast suggests a later adoption sometime after $3 \mathrm{ka}$. Actual bows or arrows have not been observed in Terminal Archaic Period contexts. Of course, actual atlatls or darts also have yet to be observed in the Titicaca Basin, indicating that absence of bowand-arrow evidence in the Terminal Archaic cannot be taken as evidence of absence. The extent to which the Late-Terminal Archaic transition reflects subsistence change, 
declining mobility, and projectile technology change thus requires continued investigation.

To be sure, it is clear that major changes occurred during the Terminal Archaic Period in the Titicaca Basin. This much is evident in the fact that food production, sedentism, and archery technology are well established in the subsequent Formative Period (Hastorf, 2008; Janusek, 2004; Owen, 1998; Stanish, 2003). What remains unclear is the extent to which these socioeconomic transformations first appeared in the Late Archaic, Terminal Archaic, or Formative periods. Understanding the tempo and order in which these behaviors emerged allows us to assess causal relationships among them and other behaviors such as resource privatization, territoriality, sexual division of labor, and hierarchy.

Toward advancing our understanding of socioeconomic change between the Late and Terminal Archaic periods on the Andean Altiplano, this analysis examines lithic technology across the transition. Lithic technology is not only the best preserved and most ubiquitous cultural material on the Altiplano, but it is also directly related to patterns of mobility, subsistence, and other dimensions of technology. At our disposal are two large lithic assemblages from well-dated habitation sites in the Ilave drainage of the Titicaca Basin-one assemblage from the Middle/Late Archaic Period site of Soro Mik'aya Patjxa and the other from the Terminal Archaic Period site of Jiskairumoko. In the analysis presented here, we first develop a model for the effects of mobility, subsistence, and projectile technology on lithic assemblage variation. We then derive a series of empirical expectations from the model and compare the expectations to the Soro Mik'aya Patjxa and Jiskairumoko lithic assemblages.

\section{The Effects of Diet, Mobility, and Technology on Lithic Assemblages}

We begin our analysis by modeling the effects of changing diet, mobility, and projectile technology on lithic assemblages. Archaeologists have spilled considerable ink articulating these connections, which are often complex, equifinal, and interacting. In the interest of generating testable predictions for the Titicaca Basin assemblages, we attempt to identify the largest effects, distilling them into a simple model that links diet, mobility, and technology to lithic assemblage structure.

\section{Diet and Lithics}

We first consider the effects of diet on flaked stone assemblage structure. At a basic level, lithic technology can be expected to respond to animal versus plant procurement. Quite simply, large mammal hunting is often reliant upon some form of projectile technology. Gathering is not. Projectile points should therefore figure prominently in lithic assemblages created by economies that emphasize large mammal hunting. Plant foraging and farming economies should produce comparatively few projectile points. This is not to suggest that projectile points should be altogether absent among economies that emphasized foraging. Nonetheless, we should expect quantitative differences in investment in projectile technology between economies that emphasize hunting versus those that emphasize gathering. Importantly, this prediction is largely 
restricted to the Americas where flaked stone projectile point technology was ubiquitous through time and across space.

Beyond the simple observation that lithics go hand-in-hand with hunting, we see little direct effect of general subsistence practices on flaked stone lithic technology. To be sure, we can envision indirect effects, but we reserve those effects for our consideration of mobility and projectile technology. We furthermore acknowledge that social factors, especially con-specific violence, can affect investment in projectile technology. We therefore remain alert to independent evidence that might suggest changing levels of inter-personal violence. For now, we assume that if foraging or farming intensified across the Late-Terminal Archaic boundary as previous research suggests, we should expect to observe a decrease in projectile point frequencies in lithic assemblages.

\section{Mobility and Lithics}

Next, we consider the effects of mobility on lithic assemblages. Again, considerable theoretical work has gone into establishing links between patterns of mobility and lithic assemblage structure. We wish to identify a few of the strongest effects here. Perhaps the most obvious relates to raw material provenance. Because residentially mobile individuals tend to move more and cover larger territories than residentially sedentary individuals, the lithics of mobile individuals will tend to move across larger geographic expanses than those of sedentary individuals. With each residential move, mobile individuals transport their toolkits, which contain implements made from local materials or materials from previous residences. Those tools may be discarded at subsequent residential loci. To be sure, a number of other factors can affect raw material distributions in ways that overwhelm the effects of mobility (Hughes, 2011). Residentially sedentary individuals may, for example, acquire toolstone from distant sources via long-ranging logistical forays or trade. Nonetheless, mobility fundamentally affects raw material distributions. If sedentism decreased appreciably between the Late and Terminal Archaic periods, we should expect to observe a decrease in the fraction of nonlocal materials between the Late and Terminal Archaic assemblages.

Another theoretical link between mobility and lithic structure relates to core reduction strategies (Kelly, 1988; Kuhn, 1994). Residentially mobile populations must be spartan in their possessions, like backpackers who strive to cut every ounce of weight from their pack. This is particularly the case in material-sparse landscapes (McCall, 2012). One way to minimize the burden of weight in lithic cutting tools is to reduce raw material mass relative to utility (Kuhn, 1994). This can be accomplished several ways. The simplest solution is to minimize flake mass. Of course, lost mass tends to result in lost utility. That is, on average, smaller flakes produce less cutting edge. We might therefore expect any mass savings to be shed in flake thickness to minimize mass while preserving cutting edge. Thus, we should expect declining mobility to be reflected in an increase in average flake thickness.

Yet another means by which one can shed flake mass while maintaining utility is by controlling flake aspect ratio or elongation. This argument follows from the simple geometric fact that perimeter:area ratio increases with aspect ratio (Fig. 1). Flake elongation fundamentally increases the ratio of cutting edge to area. We might therefore expect to observe a decrease in average flake elongation with increasing sedentism. It is perhaps for this reason that blade technology figured prominently among Clovis 


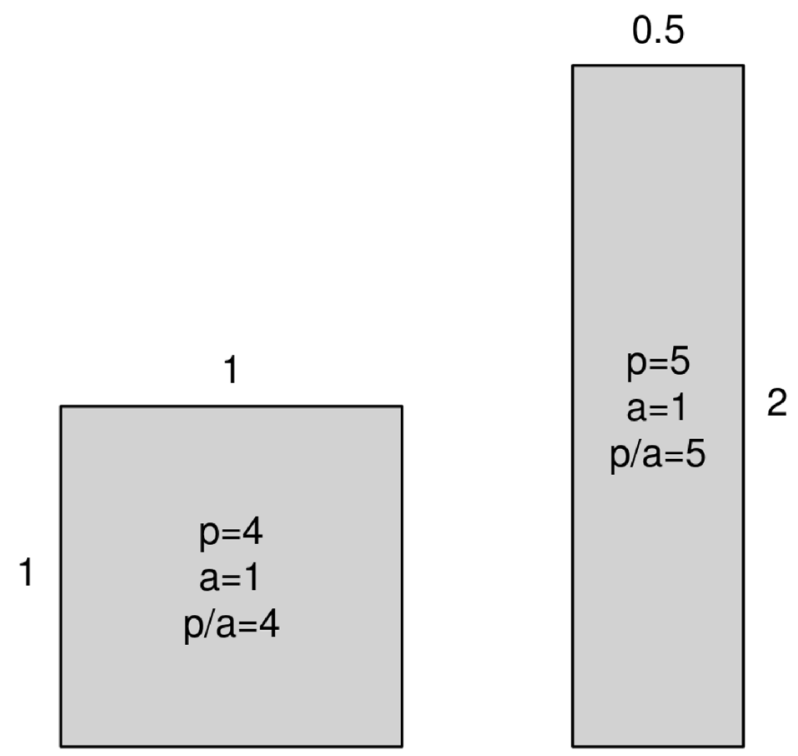

Fig. 1 Two hypothetical flakes of equal area $(a=1)$ but different perimeter lengths (p). The flake on the left has a shorter perimeter (i.e., cutting edge) than the one on the right ( $p=4$ and $p=5$, respectively) due to a difference in aspect ratio, or elongation. Thus, cutting edge:flake size ratios can be maximized by producing more elongated flakes

populations, which are largely considered the quintessential mobile hunter-gatherers (Collins, 2002).

Notably, certain sedentary cultures are well known for their blade production, which would seem to contradict the prediction presented here. Yet, it may be that the same fundamental economic dynamics are at play in both the forager and Neolithic cases if we consider how transport costs might vary among Neolithic individuals. For most sedentary individuals, lithic transport is not a major consideration. However, when stone transport and tool production becomes specialized, the cost of transport becomes high and the cost of production becomes low for the specialists who would be economically motivated and sufficiently skilled to systematically produce blades. Lacking evidence for specialized lithic industries, any changes in flake elongation would more appropriately be attributed to residential mobility patterns.

A final and related link between mobility and lithic technology considered here involves core morphology. To the extent that mobile individuals value low-mass, high utility flakes, certain core reduction strategies can help achieve that end. Several scholars have reasoned that bifacial core reduction tends to generate thinner flakes than non-systematic or expedient reduction of cores (Kelly, 1988). Again, this logically follows from basic geometry. Flakes removed from the face of a biface, which is relatively flat, will tend to be thinner than those removed from an angled surface such as from the edge of a cube. A residentially mobile individual seeking to minimize the mass of flake tools relative to cutting edge ought to invest more in bifacial core reduction than expedient core reduction. Reduced mobility can therefore be expected to result in a decrease in bifacial core frequency and increase in expedient core 
frequency. As a corollary, we should expect a decrease in the frequency of bifacial thinning flakes and increase in the frequency of expedient flakes, respectively.

In sum, if mobility declined appreciably between the Late and Terminal Archaic periods in the Titicaca Basin, we should expect to observe a decrease in average flake thickness, an increase in average flake aspect ratio, a decrease in the frequency of bifacial cores with concomitant decrease in bifacial thinning flakes, and an increase in the frequency of expedient cores with concomitant increase in expedient flakes.

\section{Projectile Technology and Lithics}

Railey (2010) contested prior research that causally linked lithic assemblage structure to mobility. Instead, he proposed that differences in projectile propulsion systems could better account for observed differences in archaeological lithic assemblages. In this view, the transition from atlatl to archery technology is foregrounded. We focus on a few of Railey's key arguments to deduce predictions for lithic assemblage structure on the Andean Altiplano.

First and foremost, the transition of from atlatl to archery technology can be expected to induce a decrease in average projectile point size. In broad terms, atlatl darts are large and require larger projectile points. Arrows are small and require smaller points. While it is well known that small points can be used with atlatl darts and large points can be used with arrows, the analysis of ethnographic and archaeological darts and arrows shows strong quantitative relationships between projectile technology and point size (Hildebrandt \& King, 2012; Shott, 1997; Thomas, 1978). Thus, if the Late/ Terminal Archaic Period boundary corresponds to a transition from atlatl to archery technology, we should observe a decrease in average projectile point size across empirically derived size thresholds. As a corollary, we should also expect average flake size to decrease given that flakes were removed from bifaces of decreasing size over time. Specific proxy measures of projectile point size are presented in "Materials and Methods" below.

Archery technology can also be expected to induce changes in lithic reduction strategies. Although those changes can be reflected in a number of dimensions of variation (Odell, 1988), we focus here on biface production, which is the most archaeologically ubiquitous projectile technology in the Americas. Both dart and arrow points tend to be shaped from bifacially reduced flakes or cores. They may be reduced to preforms using freehand percussion techniques, especially soft hammer percussion or pressure flaking. The margins may then be retouched with pressure flaking (Andrefsky, 2005; Whittaker, 1994). Despite this common trajectory, dart and arrow point reduction sequences differ in emphasis. Because dart points are larger, early-stage reduction strategies require a high degree of force to drive flakes across the biface center line - a requirement for thinning bifaces. Freehand percussion may be necessary to generate sufficient force in such cases. Smaller arrow points, in contrast, do not require such a degree of force to achieve bifacial thinning. Most if not all of the thinning process can be accomplished by pressure flaking. Not only is pressure flaking sufficient for arrow point production, but it is also advantageous insofar as it offers more control in flake removal resulting in more efficient reduction and lower breakage rates than could be achieved by freehand percussion. Thus, whereas dart point production emphasizes both freehand percussion and pressure flaking, arrow point production 
emphasizes pressure flaking. The transition from atlatl to archery technology could therefore be expected to result in a reduction in flake size, reduction in the frequency of bifacial thinning flakes, and increase in the frequency of pressure flakes.

Finally, the bow and arrow can be expected to affect raw material choice. Because arrow points are smaller than dart points, arrow point producers are less beholden to raw material size. Dart producers must obtain large cores to achieve the size requirements of dart points. We should therefore expect the transition from atlatl to archery technology to induce a shift in raw material preference with decreasing emphasis on raw material size.

In sum, the archery sub-model leads us to predict a decrease in projectile point size across empirically defined dart/arrow point size thresholds, a decrease in bifacial thinning flake frequency, an increase in pressure flake frequency, and a decrease in emphasis on large raw materials.

\section{Synthesis}

To this point, we have outlined general predictions for lithic assemblages under the assumption of changing diet, mobility, and technology. Table 1 integrates the three submodels and their general predictions. Note that some predictions are convergent. For example, the diet, mobility, and projectile technology models all predict a decrease in bifacial thinning flakes, albeit for different reasons. Moreover, some models are agnostic with respect to some dependent variables. For example, while it is clear that declining emphasis on hunting should induce a decline in projectile point frequency, there is no intrinsic reason - to our knowledge - that we should expect the transition from darts to arrows to exert a strong effect on the frequency of projectile points given that both technologies use projectile points. Thus, in cases of no effect, our prediction is that those variables ought to remain statistically constant across the Late-Terminal Archaic period boundary.

This model formulation recognizes that candidate behaviors are not mutually exclusive. Diet, mobility, and projectile technologies are all tightly linked behaviors. The human system archaeologists work with are not well controlled, so our tests should not be designed as such. We therefore take something of an information theoretic approach, at least conceptually, which attempts to identify the candidate model that captures the most empirical variation with the fewest theoretical assumptions (Fogelin, 2007; McElreath, 2016). At the outset, we consider that all possible combinations of the hypothesized behaviors are possible. For example, we could envision a dramatic decrease in mobility, a moderate change in subsistence, and no change in subsistence technology. We further acknowledge that some effects may mask others, potentially leading to false negatives in behavior identifications. Nonetheless, we consider that some of the candidate behaviors were more prominent than others, and that we should be able to detect those in lithic assemblages. Hypothesized shifts from hunting to gathering, residential mobility to sedentism, and atlatl to archery technology range from a large shift to a small shift to no shift at all for each of the three sub-models. In selecting the best behavioral model from the range of infinite possibilities, we seek to identify the combination that accounts for the most dependent variation in the lithic assemblages with the fewest systemic and archaeological assumptions. 
Table 1 Behavioral changes and predicted major effects on lithic variables for the Titicaca Basin LateTerminal Archaic transition

\begin{tabular}{|c|c|c|c|c|}
\hline \multicolumn{2}{|c|}{ Lithic variable } & \multicolumn{3}{|l|}{ Behavioral change } \\
\hline Class & Variable & Hunting $\rightarrow$ gathering & Mobile $\rightarrow$ sedentary & Atlatl $\rightarrow$ bow \\
\hline Core & Expedient & No effect & Increase & No effect \\
\hline Core & Bifacial & No effect & Decrease & No effect \\
\hline Flake & Mass & No effect & Increase & Decrease \\
\hline Flake & Area & No effect & No effect & Decrease \\
\hline Flake & Thickness & No effect & Increase & Decrease \\
\hline Flake & Aspect ratio & No effect & Decrease & No effect \\
\hline Flake & Bending initiation & Decrease & Decrease & Decrease \\
\hline Flake & Dorsal flake scars & Decrease & Decrease & Decrease \\
\hline Flake & Thickness:mass & Decrease & Decrease & Decrease \\
\hline Point & Width & No effect & No effect & Decrease \\
\hline Point & Thickness & No effect & No effect & Decrease \\
\hline Point & Mass & No effect & No effect & Decrease \\
\hline Point & Frequency & Decrease & No effect & No effect \\
\hline Material & Local (\% chert) & No effect & Increase & No effect \\
\hline Material & Size (\% igneous) & No effect & No effect & Decrease \\
\hline
\end{tabular}

\section{Materials and Methods}

Our analysis is specifically concerned with lithic assemblages from two sites that span the transition from mobile hunter-gatherer to low-level agropastoral lifeways in the Andean highlands of South America. The two sites, Soro Mik'aya Patjxa and Jiskairumoko, are located on the same alluvial plain just seven $\mathrm{km}$ apart within the Ilave drainage of the southern Lake Titicaca Basin, Peru (Fig. 2). In nearly every regard, the sites exist in the same ecological context, making them ideal for temporal and socioeconomic comparison. The occupations are separated by at least 1.5 millennia with Soro Mik'aya Patjxa characterized as a mobile hunter-gatherer residential site and Jiskairumoko characterized as a horticultural, or low-level food production (Smith, 2001), residential site. Here, we briefly describe these two sites, model-derived predictions for their lithic assemblages, and analytical methods used to examine the lithics and evaluate predictions.

\section{Soro Mik'aya Patjxa}

Soro Mik'aya Patjxa (Ilave 95-259) is a Middle/Late Archaic Period (9.0-5.0 cal. ka) hunter-gatherer site located near the geographic center of the Ilave Basin, approximately half a kilometer from the perennial Huenque River (Haas \& Viviano Llave, 2015). The site is a near-surface artifact scatter covering approximately .28 ha. Excavation of $50 \mathrm{~m}^{2}$ revealed 16 intact cultural pit features and over 80,000 artifacts including lithics, animal bone, informal groundstone, ocher, and charcoal all indicative of a habitation 

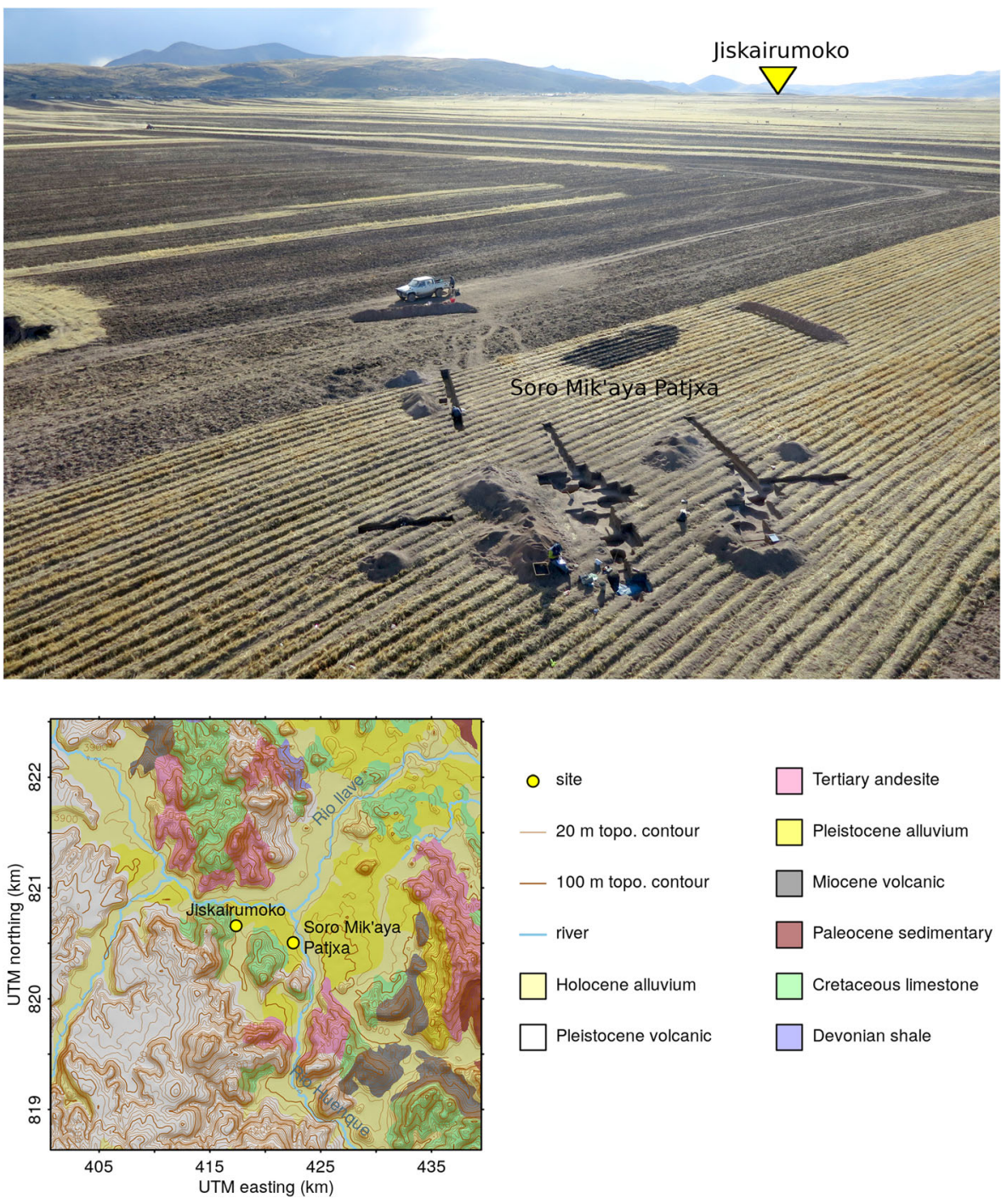

Fig. 2 Environmental context of the study sites. Both sites are located on an alluvial terrace in the Ilave Basin on the Andean Altiplano. Top: Soro Mik'aya Patjxa with excavation units in the foreground, Jiskairumoko in the background. Bottom: Geologic (Schenk et al., 1999) and topographic (Danielson \& Gesch, 2011) context of the sites. The major lithic source is river gravels associated with the Ilave and Huenque Rivers (Haas et al., 2017) and lag gravels in the surrounding alluvial deposits. Coordinate system: UTM 19S (WGS 84)

site, albeit one in which habitation was non-permanent and repetitive. A suite of 19 radiocarbon dates on paleobotanicals and human skeletal remains from 12 features place the occupation securely between 8.0 and 6.5 cal. ka (Table 2). Lithics are by far the most abundant artifact class, comprising $85 \%$ of the assemblage. Projectile points are numerous $(n=282)$, and nearly all diagnostic points are Middle and Late Archaic Period dart forms, particularly 4D and 3F forms, suggestive of large mammal atlatl hunting (Fig. 3; Table 3) (Haas et al., 2015; Klink \& Aldenderfer, 2005). The pit features observed at Soro Mik'aya Patjxa consist primarily of small human burial pits 
Table 2 Radiocarbon dates for Soro Mik'aya Patjxa (Haas et al., 2017) and Jiskairumoko (Craig, 2012). Calibration uses the 2020 Southern Hemisphere calibration curve (Haslett \& Parnell, 2008; Hogg et al., 2020)

\begin{tabular}{|c|c|c|c|c|c|c|c|}
\hline \multirow[t]{2}{*}{ Site } & \multirow[t]{2}{*}{ Lab ID } & \multirow[t]{2}{*}{ Material } & \multirow[t]{2}{*}{ Context } & \multicolumn{2}{|c|}{${ }^{14} \mathrm{C}$ B.P. } & \multicolumn{2}{|c|}{ 95\% cal. B.P } \\
\hline & & & & Age & Error & Max & Min \\
\hline Soro Mik'aya Patjxa & AA102848 & Wood & Feature 10: burial & 5891 & 49 & 6789 & 6500 \\
\hline Soro Mik'aya Patjxa & AA102854 & Wood & Feature 14: burial & 5914 & 35 & 6794 & 6563 \\
\hline Soro Mik'aya Patjxa & AA102843 & Wood & Feature 16: burial & 5924 & 48 & 6850 & 6558 \\
\hline Soro Mik'aya Patjxa & AA102828 & Wood & Feature 3: burial & 5940 & 49 & 6884 & 6565 \\
\hline Soro Mik'aya Patjxa & AA102851 & Bark? & Feature 9: pit & 5957 & 48 & 6891 & 6632 \\
\hline Soro Mik'aya Patjxa & AA102859 & Wood & Feature 18: burial & 5983 & 47 & 6934 & 6660 \\
\hline Soro Mik'aya Patjxa & AA 102858 & Wood & Feature 15: pit & 5996 & 51 & 6936 & 6668 \\
\hline Soro Mik'aya Patjxa & AA102834 & Parenchyma & Feature 6: pit & 6002 & 48 & 6936 & 6671 \\
\hline Soro Mik'aya Patjxa & AA102855 & Parenchyma & Feature 14: burial & 6003 & 50 & 6937 & 6672 \\
\hline Soro Mik'aya Patjxa & AA102837 & Parenchyma & Feature 13: burial & 6089 & 49 & 7154 & 6744 \\
\hline Soro Mik'aya Patjxa & AA102829 & Parenchyma & Feature 3: burial & 6103 & 48 & 7156 & 6750 \\
\hline Soro Mik'aya Patjxa & AA102835 & Twig & Feature 6: pit & 6148 & 50 & 7160 & 6803 \\
\hline Soro Mik'aya Patjxa & AA102842 & Twig & Feature 13: burial & 6157 & 49 & 7161 & 6805 \\
\hline Soro Mik'aya Patjxa & AA 107490 & left rib of burial 16 & Feature 18: burial & 6259 & 38 & 7254 & 6996 \\
\hline Soro Mik'aya Patjxa & AA102827 & grass stem & Feature 2: burial & 6401 & 50 & 7421 & 7166 \\
\hline Soro Mik'aya Patjxa & AA102831 & grass stem & Feature 5: pit & 6458 & 71 & 7473 & 7167 \\
\hline Soro Mik'aya Patjxa & AA107345 & right rib of burial 9 & Feature 13: burial & 6529 & 40 & 7505 & 7284 \\
\hline Soro Mik'aya Patjxa & AA102826 & Parenchyma & Feature 2: burial & 6631 & 50 & 7576 & 7424 \\
\hline Soro Mik'aya Patjxa & AA102838 & Twig & Feature 13: burial & 7090 & 59 & 8007 & 7737 \\
\hline Jiskairumoko & AA36819 & Charcoal & House 2 & 3411 & 51 & 3821 & 3458 \\
\hline Jiskairumoko & AA36814 & Charcoal & House 2 & 3838 & 75 & 4414 & 3981 \\
\hline Jiskairumoko & AA36818 & Charcoal & House 2 fill & 3620 & 48 & 4079 & 3718 \\
\hline Jiskairumoko & AA36815 & Charcoal & Burial 2 & 3733 & 43 & 4223 & 3894 \\
\hline Jiskairumoko & AA36817 & Charcoal & Burial 1 & 4375 & 46 & 5213 & 4827 \\
\hline Jiskairumoko & AA36816 & Charcoal & Pit feature & 3390 & 54 & 3819 & 3449 \\
\hline Jiskairumoko & AA36813 & Charcoal & Fill & 4148 & 43 & 4823 & 4448 \\
\hline Jiskairumoko & AA36820 & Charcoal & Pit oven 2 & 3448 & 47 & 3829 & 3493 \\
\hline Jiskairumoko & AA43380 & Charcoal & House 3 fill & 3214 & 50 & 3484 & 3241 \\
\hline Jiskairumoko & AA43381 & Charcoal & House 3 fill & 3299 & 42 & 3573 & 3376 \\
\hline Jiskairumoko & AA43373 & Charcoal & House 3 midden & 3378 & 46 & 3698 & 3450 \\
\hline Jiskairumoko & AA43382 & Charcoal & House 3 hearth & 3382 & 48 & 3811 & 3451 \\
\hline Jiskairumoko & AA43383 & Charcoal & House 3 hearth & 3448 & 44 & 3829 & 3495 \\
\hline Jiskairumoko & AA43376 & Charcoal & Midden & 3330 & 45 & 3680 & 3397 \\
\hline Jiskairumoko & AA43375 & Charcoal & Hearth & 3401 & 45 & 3815 & 3459 \\
\hline Jiskairumoko & Beta-97320 & Charcoal & House 1 midden & 3410 & 60 & 3824 & 3454 \\
\hline Jiskairumoko & Beta-97321 & Charcoal & Midden & 3240 & 70 & 3576 & 3226 \\
\hline Jiskairumoko & AA43379 & Charcoal & House 1 & 4547 & 95 & 5450 & 4865 \\
\hline Jiskairumoko & AA45952 & Charcoal & House 1 & 3235 & 58 & 3566 & 3247 \\
\hline Jiskairumoko & AA58475 & Charcoal & House 1 hearth & 3208 & 58 & 3556 & 3216 \\
\hline
\end{tabular}


Table 2 (continued)

\begin{tabular}{|c|c|c|c|c|c|c|c|}
\hline \multirow[t]{2}{*}{ Site } & \multirow[t]{2}{*}{ Lab ID } & \multirow[t]{2}{*}{ Material } & \multirow[t]{2}{*}{ Context } & \multicolumn{2}{|c|}{${ }^{14}$ C B.P. } & \multicolumn{2}{|c|}{ 95\% cal. B.P. } \\
\hline & & & & Age & Error & $\operatorname{Max}$ & Min \\
\hline Jiskairumoko & AA36812 & Charcoal & Plow zone & 4726 & 44 & 5574 & 5317 \\
\hline Jiskairumoko & AA43372 & Charcoal & House 2 fill & 3428 & 63 & 3829 & 3460 \\
\hline Jiskairumoko & AA43377 & Charcoal & Burial 3 & 3341 & 45 & 3685 & 3402 \\
\hline Jiskairumoko & AA43374 & Charcoal & Burial 3 & 3450 & 45 & 3829 & 3495 \\
\hline Jiskairumoko & AA58476 & Charcoal & House 1 hearth & 4562 & 73 & 5444 & 4883 \\
\hline Jiskairumoko & AA45951 & Charcoal & Burial 4 & 3573 & 50 & 3975 & 3649 \\
\hline
\end{tabular}

and functionally non-diagnostic pits possibly used for storage or cooking. Dental wear patterns observed among the human burials are consistent with mixed terrestrial plant and animal diets with heavy investment in tubers (Watson \& Haas, 2017).

Ceramic technology and evidence of domestic architecture are notably absent from Soro Mik'aya Patjxa, suggesting a degree of residential mobility. However, mechanized plowing in recent decades has likely erased evidence of domestic architecture. Examination of mobility patterns using stable isotope chemistry on human bone, demographic analysis of human burials, lithic raw material assessment, and geographic analysis all indicate that the inhabitants of Soro Mik'aya Patjxa were full-time residents of the highlands and did not practice any detectable degree of vertical transhumance (Haas et al., 2017).

\section{Jiskairumoko}

Jiskairumoko (Ilave 95-189) is an on open air site located on the northern margin of the Rio Ilave Basin with occupation principally situated in the Terminal Archaic Period (5.0-3.5 cal. ka). It is located approximately $2 \mathrm{~km}$ from the perennial Ilave River. The site covers .36 ha and, like Soro Mik'aya Patjxa, consists of a dense scatter of lithic debris, animal bone, groundstone, ocher, and charcoal. Unlike Soro Mik'aya Patjxa, Jiskairumoko includes ceramic artifacts. Twenty-five radiocarbon dates on both charcoal and human bone from numerous secure feature contexts indicate occupation of the site that also spanned approximately 1500 years from 5.2 to $3.5 \mathrm{cal}$. ka (see Table 2). Projectile points are frequent suggesting continued investment in big game hunting. Point types are overwhelmingly small Terminal Archaic and Formative period forms including 4F, 5B, and 5C types (see Table 3 and Fig. 3) (Craig, 2012; Haas et al., 2015) that are suspected to have been associated with both atlatl and archery technologies (Klink \& Aldenderfer, 2005).

Unlike at Soro Mik'aya Patjxa, distinct architectural features exist at Jiskairumoko, including packed earth floors, kitchen rocks, fire altered rock concentrations, and distinct ashy sheet midden deposits. Craig (2012) proposes the site inhabitants constructed relatively robust, round and rectangular structures perhaps bounded by walls of hide or brush. Ceramic technology is present, albeit rare, at Jiskairumoko and represents the earliest ceramic assemblage in the Ilave Basin (Craig, 2012). The groundstone assemblage at Jiskairumoko is more extensive than that of Soro Mik'aya Patjxa with numerous mano and metate fragments. A sample of these grinding stones produced 
starch grains from cultivated or domesticated potato (Solanum tuberosum) (Rumold \& Aldenderfer, 2016) consistent with models that place plant cultivation and incipient agriculture in the Terminal Archaic Period (Bruno, 2006).

Jiskairumoko is also well known for producing the earliest use of gold ornamentation in the Americas (Aldenderfer et al., 2008). This early use of gold along with newfound interest in obsidian artifacts (Craig, 2012) suggests increasing exchange and concern with prestige. The convergence of semi-subterranean house structures, incipient ceramic technology, groundstone, and possible potato starch grains suggests an increasing degree of residential sedentism and food production relative to that which is inferred at Soro Mik'aya Patjxa.

\section{The Lithic Assemblages}

The archaeological deposits of both sites are shallow and partially mixed. Soro Mik'aya Patxja has experienced mechanical plowing extending as much as $30 \mathrm{~cm}$ below the surface. Jiskairumoko was subject to shallower animal-traction plowing with mechanized tillage on the northern margins of the site. To minimize the potential effects of assemblage mixing, our analysis is focused on temporally diagnostic artifacts (i.e., projectile points) and artifacts from secure deposits unaffected by plowing. In all, contexts examined include 6568 lithic artifacts (Table 4). To control for methodological differences in artifact collection strategies, particularly screen mesh size differences, we only examine debitage with a maximum dimension exceeding $2 \mathrm{~cm}$ in length, bringing the analyzed sample size to 3213 artifacts, including 1888 from Soro Mik'aya Patjxa and 1325 from Jiskairumoko.
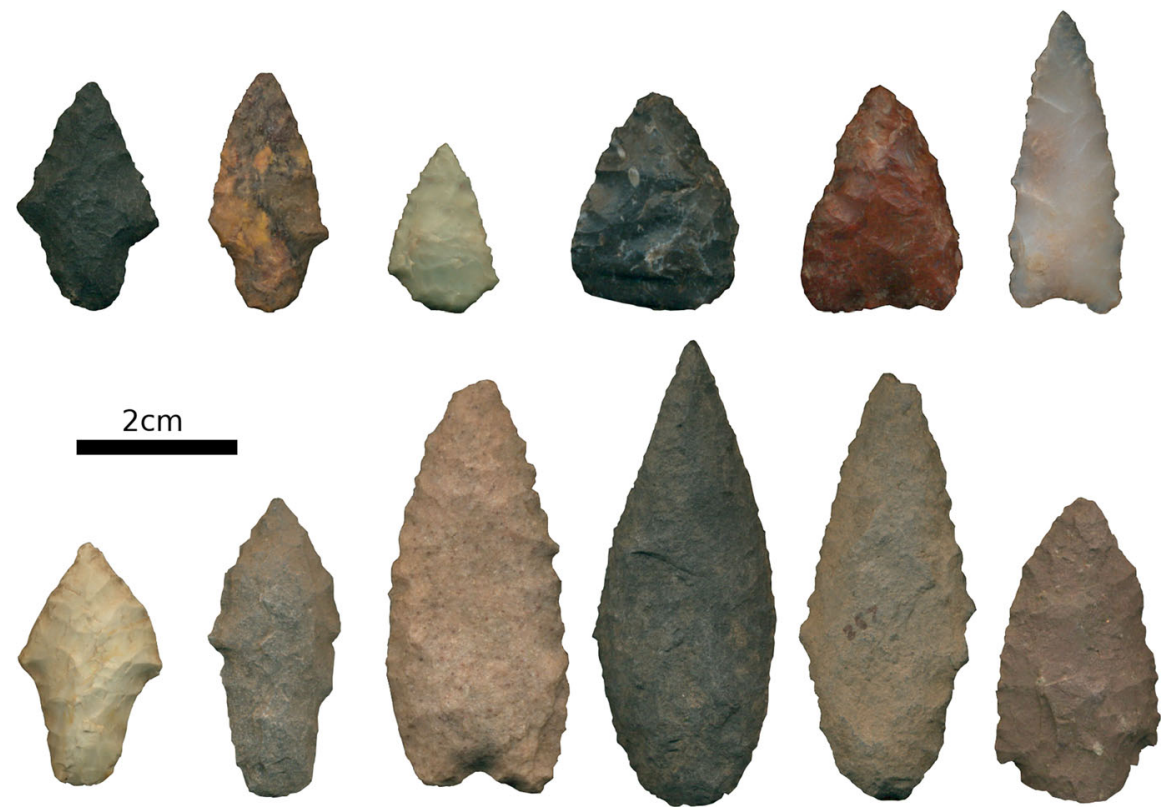

Fig. 3 Projectile point examples from Jiskairumoko (top row) and Soro Mik'aya Patjxa (bottom row). From top left to bottom right, types include $4 \mathrm{~F}(\times 3), 5 \mathrm{~B}(\times 2), 5 \mathrm{D}, 2 \mathrm{~A}(\times 2), 3 \mathrm{~F}, 3 \mathrm{D}, 3 \mathrm{~B}, 4 \mathrm{D}$ (Klink \& Aldenderfer, 2005; 52-54); raw materials include igneous, chert $(\times 6)$, igneous, quartzite, and igneous $(\times 3)$ stone 
Table 3 Temporally diagnostic projectile points collected from the surface of Soro Mik'aya Patjxa and Jiskairumoko. Column percentages in parentheses. Typology following Klink and Aldenderfer (2005)

\begin{tabular}{llll}
\hline Series/type & Period & Soro Mik'aya Patjxa & Jiskairumoko \\
\hline 5B & Terminal Archaic/Formative & $0(0)$ & $6(35)$ \\
5D & Terminal Archaic/Formative & $0(0)$ & $3(18)$ \\
4F & Terminal Archaic & $3(3)$ & $4(24)$ \\
3F & Late Archaic & $13(12)$ & $0(0)$ \\
4D & Late Archaic & $25(23)$ & $1(6)$ \\
3B & Middle Archaic & $9(8)$ & $0(0)$ \\
2A & Early/Middle Archaic & $3(3)$ & $1(6)$ \\
1B & Early Archaic & $2(2)$ & $1(6)$ \\
3D & Early-Terminal Archaic & $49(45)$ & $1(6)$ \\
3- & Early-Terminal Archaic & $6(5)$ & $0(0)$ \\
& Total & $282(100)$ & $17(100)$ \\
\hline
\end{tabular}

Because temporally diagnostic projectile points from Soro Mik'aya Patjxa are almost entirely Middle and Late Archaic Period forms and Jiskairumoko projectile points are almost entirely Terminal Archaic Period forms, the inclusion of projectile points from both secure and disturbed contexts is likely to yield temporally meaningful results. Debitage analysis, in contrast, is restricted to artifacts from secure stratigraphic contexts to avoid inadvertent inclusion of artifacts from extraneous time periods. At Soro Mik'aya Patxja, secure contexts included 13 well-defined pit features extending below the modern plow zone. Eight of the pit features contained one or more human burials. The other pit features did not contain functionally diagnostic materials. All temporally diagnostic materials and radiocarbon dates from within these features date to the Middle and Late Archaic periods (Haas et al., 2017), and ceramics are entirely absent indicating that the feature contents securely pre-date the Terminal Archaic Period (Haas \& Viviano Llave, 2015). For Jiskairumoko, we focus our analysis on materials from Block 4, stratigraphic levels VII and VIII. These deposits were sealed below a rectangular floor feature and date to the Terminal Archaic Period, 3.7-3.6 cal. ka (Craig, 2012). We randomly sampled 15 of the $281 \times 1 \mathrm{~m}$ excavation units from the block (see Table 4).

\section{Data Collection and Statistical Methods}

The archaeological indicators of economic organization described above tentatively suggest a trajectory of declining emphasis on hunting and increasing emphasis on gathering and cultivation, increasing sedentism, and a transition from atlatl-and-dart to bow-and-arrow technology, each beginning at some point after the occupation of Soro Mik'aya Patjxa and possibly during the occupation Jiskairumoko. These behavioral changes anticipate a series of trends across the respective lithic assemblages, which we outlined above. Here, we describe our methods of testing those predictions.

Lithic analytical techniques follow standard procedures for the analysis of debitage and tools (Andrefsky, 2005). All length measurements are recorded to a tenth of a 
Table 4 Contexts and frequencies of lithic artifacts from sub-surface contexts examined in this study. Jiskairumoko artifacts from Block 4

\begin{tabular}{|c|c|c|c|c|c|c|}
\hline \multirow[t]{2}{*}{ Site } & \multirow[t]{2}{*}{ Context } & \multirow[t]{2}{*}{ Bifaces } & \multirow[t]{2}{*}{ Cores } & \multicolumn{2}{|c|}{ Debitage } & \multirow[t]{2}{*}{ Total } \\
\hline & & & & $>2 \mathrm{~cm}$ & $<2 \mathrm{~cm}$ & \\
\hline SMP & Feature 1 & 1 & 0 & 62 & 102 & 165 \\
\hline SMP & Feature 2 & 5 & 1 & 192 & 502 & 700 \\
\hline SMP & Feature 3 & 0 & 0 & 1 & 0 & 1 \\
\hline SMP & Feature 4 & 2 & 2 & 24 & 245 & 273 \\
\hline SMP & Feature 6 & 1 & 2 & 783 & 1320 & 2106 \\
\hline SMP & Feature 7 & 0 & 0 & 1 & 0 & 1 \\
\hline SMP & Feature 10 & 1 & 1 & 252 & 190 & 444 \\
\hline SMP & Feature 13 & 5 & 1 & 43 & 28 & 77 \\
\hline SMP & Feature 14 & 4 & 0 & 0 & 0 & 4 \\
\hline SMP & Feature 15 & 1 & 0 & 0 & 0 & 1 \\
\hline SMP & Feature 16 & 1 & 0 & 36 & 12 & 49 \\
\hline SMP & Feature 17 & 0 & 0 & 1 & 0 & 1 \\
\hline \multirow[t]{2}{*}{ SMP } & Plow zone & 395 & 40 & 30 & 0 & 465 \\
\hline & Site total & 416 & 47 & 1425 & 2399 & 4287 \\
\hline Jiska. & Feature 1 & 15 & 1 & 492 & 355 & 863 \\
\hline Jiska. & Feature 2 & 10 & 2 & 298 & 235 & 545 \\
\hline Jiska. & Feature 3 & 0 & 0 & 15 & 15 & 30 \\
\hline Jiska. & Feature 4 & 1 & 0 & 0 & 0 & 1 \\
\hline Jiska. & Feature 5 & 2 & 0 & 9 & 7 & 18 \\
\hline Jiska. & Feature 6 & 21 & 3 & 213 & 168 & 405 \\
\hline Jiska. & Feature 7 & 1 & 0 & 0 & 0 & 1 \\
\hline Jiska. & Feature 8 & 1 & 0 & 83 & 84 & 168 \\
\hline Jiska. & Feature 10 & 0 & 0 & 20 & 9 & 29 \\
\hline Jiska. & Feature 11 & 0 & 0 & 16 & 14 & 30 \\
\hline Jiska. & Feature 12 & 0 & 1 & 28 & 18 & 47 \\
\hline Jiska. & Feature 17 & 1 & 0 & 0 & 0 & 1 \\
\hline Jiska. & Feature 22 & 0 & 0 & 1 & 1 & 2 \\
\hline Jiska. & Feature 25 & 0 & 0 & 10 & 14 & 24 \\
\hline \multirow[t]{3}{*}{ Jiska. } & Extramural units & 25 & 3 & 53 & 36 & 117 \\
\hline & Site total & 77 & 10 & 1238 & 956 & 2281 \\
\hline & Grand total & 493 & 57 & 2663 & 3355 & 6568 \\
\hline
\end{tabular}

millimeter using electronic calipers. All mass measurements are recorded to a tenth of a gram using an electronic balance. Contingency tables and chi-squared tests are used to assess statistical significance for observed differences in frequency data. Box plots and Kolmogorov-Smirnov (KS) tests are used to assess statistical significance of observed differences between length and mass data. Most attributes are relatively straightforward, but four attributes — cores, bifacial thinning flakes and pressure flakes, projectile point size, and raw materials-require additional explanation. 


\section{Cores}

Our theoretical goal in examining cores is to differentiate highly curated, formal cores from expedient, informal cores under the assumption that these categories index high and low degrees of residential mobility, respectively. The rationale is that residentially mobile individuals are motivated to conserve raw material and maximize utility given that their high mobility precludes material stockpiling. Residentially sedentary individuals, in contrast, do not have to manage their raw material consumption so carefully. Like flakes, cores lack unambiguous, objective categories adding a degree of subjectivity to type discrimination. Following previous research (Kelly, 1988), we consider the subjective distinction between bifacial and amorphous cores to be a reasonable proxy for formal and informal core technologies, respectively.

However, as we will see, not only does the bifacial/amorphous core distinction leave some artifacts difficult to categorize, but it also produces a woefully small sample size in the particular assemblages we analyze. We therefore consider more broadly that all non-amorphous cores, including bifacial, centripetal, and tabular forms - are formal cores of sorts. In this scheme, we consider amorphous cores to be any cores lacking evidence of systematic patterned reduction strategies. Consequently, these cores are characterized by a lack of a recognizable vertical or horizontal axis or orientation (McCall et al., 2019; 169).

\section{Bifacial Thinning and Pressure Flakes}

All three models considered here predict a decrease in the relative abundance of bifacial thinning flakes, albeit for different reasons. Unfortunately, bifacial thinning flakes can be difficult to record objectively for lack of "natural" categories, and different analysts may report qualitative and quantitative variables differently even with extensive training. For example, although soft hammer and bifacial reduction tends to produce flakes with lower relative thickness values than hard hammer and amorphous core reduction (Amick et al., 1988; Prasciunas, 2007), it may be difficult to objectively measure these attributes on incomplete or modified flakes. To enhance reliability, we record three proxies of bifacial thinning that we believe are relatively reproducible (Ostahowski \& Kelly, 2014; 127). These include platform type, dorsal flake scar counts, and relative thickness.

First, we anticipate a decrease in the frequency of bifacial thinning platforms, which we qualitatively identify as those with facets or lips (Surovell 2009; Ostahowski \& Kelly, 2014). The proportion of bifacial thinning platforms to all other platforms is expected to decrease from Soro Mik'aya Patjxa to Jiskairumoko. Only flakes with platforms are considered for this portion of the analysis.

Second, we consider dorsal flake scar counts, which tend to be greater on bifacial thinning flakes than on expedient reduction flakes (Surovell 2009; Ostahowski \& Kelly, 2014). Because dorsal flake scar count may also not be recorded consistently between analysts, we also recorded this attribute as an ordinal category using a threshold of greater than three scars (Ostahowski \& Kelly, 2014; 127). The frequencies of flakes with three or fewer dorsal flakes scars are compared to the frequencies of flakes with more than three dorsal flake scars. If emphasis on expedient technology 
increased between Soro Mik'aya Patjxa and Jiskairumoko, we expect to observe a decrease in the frequency of flakes with more than three flake scars.

Third and finally, reduced emphasis on bifacial thinning anticipates an increase in flake thickness. This is for two reasons. First, as emphasis on bifacial technology declines, the relative importance of expedient flake production increases, which should have the effect of increasing average flake thickness. Second, as pressure flaking becomes increasingly important, as anticipated by the projectile technology sub-model, flake thickness increases, a pattern that has been observed empirically by Buchanan et al. (2016). Of course, flake thickness is also highly correlated with overall flake size. Since pressure flaking tends to produce smaller flakes than freehand percussion, we scale flake thickness measurements to flake mass. We expect flake thickness:mass ratios to increase between the Soro Mik'aya Patjxa and Jiskairumoko assemblages. Only complete flakes are considered in this portion of the analysis.

\section{Projectile Point Size Analysis}

The projectile technology sub-model predicts a decrease in projectile point size across empirically determined dart/arrow point size thresholds. Distinguishing dart and arrow points is objectively challenging given their formal isomorphism and overlapping sizes. We therefore consider three proxy measures of declining projectile point size that consistently show a quantitative distinction between dart and arrow points in ethnographic and archaeological assemblages in North America (Hildebrandt \& King, 2012; Shott, 1997; Thomas, 1978). Note that we do not use Hildebrandt and King's index here because it was designed for notched points - a form that does not occur in our study region. Only temporally diagnostic projectile point forms are used in these analyses, including artifacts from both mixed and secure contexts.

First, we anticipate a decrease in average projectile point width from greater than to less than $18.0 \mathrm{~mm}$. Thomas (1978) identified width to be the strongest predictor of dart versus arrow points. The 18.0-mm threshold is the midpoint of values observed in three studies. Thomas (1978) observed a threshold of $18.8 \mathrm{~mm}$, Shott (1997) observed a threshold of $18.9 \mathrm{~mm}$, and Railey (2010) observed a threshold of $17.1 \mathrm{~mm}$. We note that Shott's classification scheme uses two equations each with two terms. When the two equations are set as equalities, they reduce to a single threshold value of $18.9 \mathrm{~mm}$. All three studies are in close agreement, spanning just $2 \mathrm{~mm}$.

The second proxy for decreasing projectile point size that we consider is biface thickness. Atlatl dart shafts are considerably thicker than arrow shafts, so we should expect dart points to be thicker than arrow points on average. Empirical observations reveal a decrease in average projectile point thickness from greater than to less than $4.3 \mathrm{~mm}$ when transitioning from dart to arrow technology. This threshold is the midpoint of values observed by Thomas (1978) and Railey (2010), which are in close agreement.

The third proxy for projectile point size decrease that we consider is mass. Average projectile point mass is expected to decrease from greater than to less than $3.2 \mathrm{~g}$ when transitioning from dart to arrow technology (Thomas, 1978). Only complete points are used for this portion of the analysis.

In sum, if archery technology emerged in the Titicaca Basin during the Terminal Archaic Period, we would expect to observe average projectile point widths to decline 
across the $18.0 \mathrm{~mm}$ threshold, average thickness to decline across the $4.3 \mathrm{~mm}$ threshold, and average mass to decline across the $3.2 \mathrm{~g}$ threshold. The majority outcome will determine the favored interpretation, whether introduction of bow-and-arrow or not.

\section{Raw Materials}

The mobility sub-model predicts increasing use of local raw materials as mobility decreases. The projectile technology sub-model predicts decreasing concern with raw material size with atlatl users requiring larger materials for the production of larger projectile points. We therefore seek methods that allow us to identify (a) local versus non-local materials and (b) large versus small raw materials.

Unfortunately, we are currently unaware of any clear distinctions between local and non-local materials in the study region, with the exception of obsidian, which plays a relatively minor role in these assemblages. However, raw material surveys and previous examination of raw materials in the assemblages (Haas et al., 2017) point to a proxy measure of non-local raw material use. We have observed that the most accessible toolstone source at both sites is local river gravels, which include chert, igneous, and quartzite cobbles that can be obtained in lag deposits at or very near the sites, from the Ilave River less than $2 \mathrm{~km}$ from Jiskairumoko, or the Huenque River less than $1 \mathrm{~km}$ from Soro Mik'aya Patjxa (see Fig. 2). Virtually every material type observed in the Soro Mik'aya Patjxa assemblage can be obtained locally from the river gravels (Haas et al., 2017). The materials are extremely diverse including red, yellow, green, tan, white, and black cherts; black, gray, and pink volcanics; and white, pink, and purple quartzites.

Although these materials are readily found in local alluvial gravels, some portion of the igneous artifacts appear to exhibit non-alluvial cortex, suggesting that some portion of igneous materials were being obtained from more distant primary geologic sources, likely more than $5 \mathrm{~km}$ from the sites. Chert artifacts, in contrast, tend to exhibit alluvial cortex with greater frequency. Moreover, the local river gravels are relatively restricted in size, rarely exceeding five $\mathrm{cm}$ in diameter. Large tools and flakes exceeding this size tend to be made on igneous materials but rarely on cherts, again suggesting that some portion of igneous materials came from sources beyond local river gravels. We therefore suspect that igneous materials were, occasionally, obtained from non-local sources, likely to access larger materials. To the extent that these observations are valid, the ratio of igneous:chert artifacts can serve as a quantitative proxy for emphasis on both non-local raw materials and larger raw materials. In other words, if emphasis on local materials increased and emphasis on raw material size decreased, we should expect the frequency of igneous materials to decline and the emphasis on cherts to increase.

\section{Results}

Following from previous archaeological observations on the Andean Altiplano, our working model posits that hunting declined, plant foraging or cultivation increased, residential mobility declined, and projectile technology transitioned from atlatl to archery sometime after the Late Archaic Period during the Terminal Archaic Period. 
Given these hypothesized behavioral changes, we have deduced a series of predictions for changes in lithic assemblages. Here we examine each dependent variable in turn to determine if expectations are met relative to each of the three behavioral sub-models related to diet, mobility, and technology.

\section{Cores}

We first analyze expectations for bifacial/curated and amorphous/expedient core frequencies. The mobility sub-model anticipates a decrease in bifacial cores and corresponding increase in expedient cores. Unfortunately, and despite relatively large lithic assemblages, the sample of cores is relatively small including just 57 cores, 47 of which are from Soro Mik'aya Patjxa (Table 5; ESM 1-2). Bifacial:amorphous core frequencies are 2:31 (6\% bifacial) at Soro Mik'aya Patjxa and 0:8 (0\% bifacial) at Jiskairumoko. While these ratios trend in the predicted direction, the sample size is too small to rule out statistical chance (statistical testing would be invalid due to zero count for Jiskairumoko formal cores). It is noteworthy that there are just two bifacial cores in the sum of both assemblages, suggesting that mobility was relatively low at both sites.

To increase sample size and to capture cores that did not fit cleanly into the bifacial or expedient categories, we assumed that all non-amorphous cores-bifacial, centripetal, tabular, and other forms - are formal cores of sorts. This categorization gives formal:informal core frequencies of 16:31 (34\% formal) at Soro Mik'aya Patjxa and 2:8 ( $20 \%$ formal) at Jiskairumoko (see Table 5). Again, the trend is in the predicted direction of decreasing proportions of formal cores, but the differences are not statistically significant $\left(\chi^{2}=0.24, d f=1, p=0.62\right.$ ) leaving us unable to rule out the possibility of no change in core reduction strategies between the two sites. We therefore find weak support for the prediction, noting ambiguity due to small sample size.

The diet and projectile technology sub-models anticipate no effect on core forms. Thus, de facto support is found for the diet and projectile technology sub-models.

\section{Flakes}

We next consider flake morphology including flake mass, flake area, flake thickness, flake aspect ratio, and bifacial thinning flake frequency. For each of the metric variables, only complete flakes are considered. This includes 299 complete flakes from Soro Mik'aya Patjxa (ESM 3) and 356 from Jiskairumoko (ESM 4).

Table 5 Core forms at Soro Mik'aya Patjxa and Jiskairumoko

\begin{tabular}{lll}
\hline Core form & Soro Mik'aya Patjxa & Jiskairumoko \\
\hline Amorphous & 31 & 8 \\
Bifacial & 2 & 0 \\
Centripetal & 5 & 0 \\
Tabular & 4 & 1 \\
Other & 5 & 1 \\
Total & 47 & 10 \\
\hline
\end{tabular}


We first consider mass. Whereas the mobility sub-model anticipates an increase in flake mass due to relaxed mobility constraints, the projectile technology sub-model anticipates a decrease in average mass due to the production of smaller projectile points over time. Consistent with the latter sub-model, we observe a statistically significant (KS $D=0.11, p=0.04$ ) decrease in average flake mass from a median of $0.53 \mathrm{~g}$ at Soro Mik'aya Patjxa to $0.35 \mathrm{~g}$ at Jiskairumoko (Fig. 4a).

Next we consider flake area. The projectile technology sub-model predicts a decrease in average flake area as a result of the transition from the production of larger dart points to smaller arrow points. Consistent with this expectation, we observe a statistically significant (KS $D=0.18, p<0.01$ ) decrease in average flake area from a median of $178 \mathrm{~mm}^{2}$ at Soro Mik'aya Patjxa to $156 \mathrm{~mm}^{2}$ at Jiskairumoko (Fig. 4b).

For average flake thickness, the mobility sub-model predicts an increase as a result of decreasing emphasis on portability, and the projectile technology model predicts a decrease as a result of the transition from large dart point to small arrow point production. Consistent with the projectile technology sub-model, we observe a statistically significant decrease (KS $D=0.18, p<0.01)$ in average flake thickness from a median of $3.1 \mathrm{~mm}$ at Soro Mik'aya Patjxa to 2.9 at Jiskairumoko (Fig. 4c).

For average flake aspect ratio, the mobility sub-model predicts a decrease given the decreasing pressure to maximize cutting edge length. However, we observe a slight, non-statistically significant (KS $D=0.09, p=0.18$ ) increase in average aspect ratio
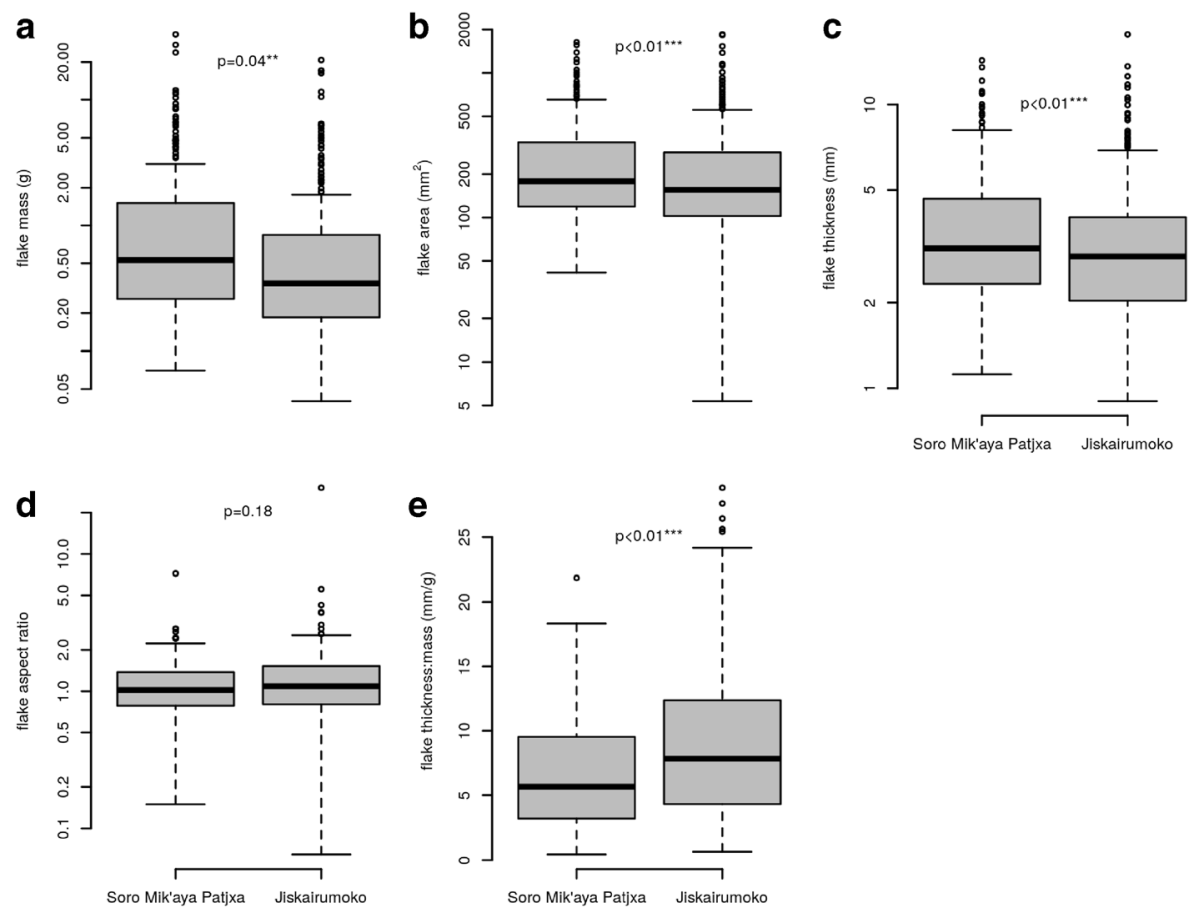

Fig. 4 Results of flake analysis comparing Soro Mik'aya Patjxa to Jiskairumoko traits. Consistent with the projectile technology model, a flake mass, $\mathbf{b}$ flake area, and $\mathbf{c}$ flake thickness all decrease significantly $(p<$ $0.05)$. Counter to the mobility model, $\mathbf{d}$ planimetric aspect ratio, or elongation, shows no significant change $(p$ $>0.1)$. Consistent with all three sub-models, e flake thickness relative to mass increases significantly $(p<$ $0.01)$. 
from a median of 1.0 at Soro Mik'aya Patjxa to 1.1 at Jiskairumoko (Fig. 4d). We therefore fail to find support for this prediction of the mobility sub-model.

Finally, for flake morphology, we consider bifacial thinning flake frequency. All three models predict a decrease in bifacial thinning flake frequency, albeit for different reasons - the diet model owing to reduced demand for projectile points, the mobility model owing to decreasing emphasis on bifacial cores, and the projectile point model owing to declining emphasis on bifacial thinning that is required for dart point manufacture while pressure flaking ostensibly remains constant. Unfortunately, bifacial thinning flakes are challenging to identify. We consider three proxies.

First, we observe that bending initiations - platforms with lipping or faceting and diffuse bulbs - decrease significantly $\left(\chi^{2}=19.6, d f=1, p<0.01\right)$ from $24 \%$ at Soro Mik'aya Patjxa to $14 \%$ at Jiskairumoko as predicted (Table 6). Second, counter to prediction, we observe an increase in the proportion of flakes with more than three dorsal flake scars from $8 \%$ at Soro Mik'aya Patjxa to $12 \%$ at Jiskairumoko (Table $7 ; \chi^{2}$ $=9.7, d f=1, p<0.01)$. Third, consistent with prediction, we observe a statistically significant (KS $D=0.18, p<0.01$ ) increase in median flake thickness:mass values from $5.6 \mathrm{~mm} / \mathrm{g}$ at Soro Mik'aya Patjxa to $7.8 \mathrm{~mm} / \mathrm{g}$ at Jiskairumoko (Fig. 4e). With two of three proxies consistent with predictions, we find overall support for the prediction of decreasing frequency of bifacial thinning flakes. We later discuss potential explanations for the one disconnect regarding dorsal flake scar counts.

\section{Projectile Points}

The projectile technology sub-model predicts a decrease in the central tendency of projectile point sizes across empirically estimated dart/arrow size threshold. For our first proxy variable, we observe that median biface width drops significantly (KS $D=$ $0.42, p<0.01$ ) from $21.4 \mathrm{~mm}$ at Soro Mik'aya Patjxa across the $17.0 \mathrm{~mm}$ threshold to $16.0 \mathrm{~mm}$ at Jiskairumoko, consistent with prediction (Fig. 5a; ESM 5-6).

For the second proxy variable, we observe that median biface thickness drops significantly (KS $D=0.57, p<0.01$ ) from $8.0 \mathrm{~mm}$ at Soro Mik'aya Patjxa to $5.6 \mathrm{~mm}$ at Jiskairumoko, consistent with prediction (Fig. 5b). However, the observed decrease in median thickness does not traverse the $4.3 \mathrm{~mm}$ thickness threshold. Instead, median thickness remains in the dart point range for both assemblages. Thus, we fail to validate the prediction of decreasing projectile point thickness across the dart/arrow point boundary.

Finally, consistent with prediction, we observe that median biface mass for complete bifaces drops from $8.9 \mathrm{~g}$ at Soro Mik'aya Patjxa to $2.3 \mathrm{~g}$ at Jiskairumoko, traversing the $3.2 \mathrm{~g}$ dart/arrow point threshold (Fig. $5 \mathrm{c}$; KS $D=0.75, p<0.01$ ). We therefore find

Table 6 Bifacial thinning flakes (BFT) as indexed by platform faceting or lipping. Row percentages in parentheses

\begin{tabular}{llll}
\hline Site & BFT & Non-BFT & Total \\
\hline Soro Mik'aya Patjxa & $159(24)$ & $503(76)$ & $662(100)$ \\
Jiskairumoko & $84(14)$ & $515(86)$ & $599(100)$ \\
\hline
\end{tabular}


Table 7 Bifacial thinning flakes as indexed by proportion of flakes with more than three dorsal flake scars. Row percentages in parentheses

\begin{tabular}{llll}
\hline Site & $>3$ dorsal flake scars & $\leq 3$ dorsal flake scars & Total \\
\hline Soro Mik'aya Patjxa & $115(8)$ & $1310(92)$ & $1425(100)$ \\
Jiskairumoko & $145(12)$ & $1089(88)$ & $1234(100)$ \\
\hline
\end{tabular}

support for the prediction of decreasing projectile point mass across the assumed dart/ arrow point mass threshold. Note that although small flakes and unifacial tools were not used in our analysis, we provide raw data for those artifacts for completeness of reporting of the lithic assemblages (ESM 7-10).

Based on the majority of proxy outcomes, we find overall support for the prediction that the central tendencies in projectile point size decreased across the dart/arrow point threshold. Median projectile point width, which tends to be the strongest predictor (Thomas, 1978), and median projectile point mass declined across the dart/arrow point thresholds from Soro Mik'aya Patjxa to Jiskairumoko. While median projectile point thickness also declined significantly $(p<0.01)$, it did not traverse the accepted dart/ arrow point threshold, tempering the certainty of the conclusion. We discuss this disconnect further in the "Discussion" section below.

The diet sub-model also predicts variation among projectile points. Because the Terminal Archaic period is thought to be marked by declining emphasis on hunting and increasing emphasis on gathering, the subsistence model leads us to expect a decrease in projectile point production. To assess this, and to control for sample size effects, we examine the ratios of bifaces to cores (Table 8). We observe a mere, non-statistically significant $\left(\chi^{2}=0.03, d f=1, p=0.85\right)$ decrease of $1 \%$ in biface frequency from $90 \%$ at Soro Mik'aya Patjxa to $89 \%$ at Jiskairumoko. It appears that projectile points did not decline in importance between the Late and Terminal Archaic periods, suggesting that hunting remained an important part of subsistence economies.
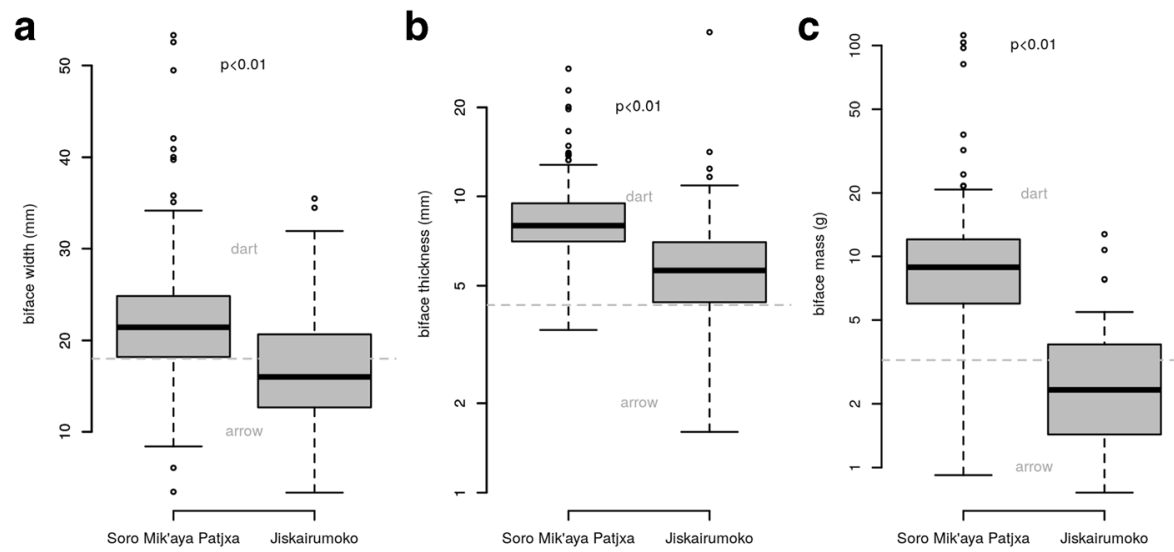

Fig. 5 Test results for Soro Mik'aya Patjxa and Jiskairumoko projectile point size analysis. a Median width decreases across accepted threshold for dart/arrow width. b Median thickness decreases but not across the accepted threshold for dart/arrow thickness. $\mathbf{c}$ Median biface mass decreases across the accepted threshold for dart/arrow mass. All trends are statistically significant $(p<0.01)$ 
Table 8 Biface and core frequencies at Soro Mik'aya Patjxa and Jiskairumoko. Row percentages in parentheses

\begin{tabular}{llll}
\hline Site & Biface & Core & Total \\
\hline Soro Mik'aya Patjxa & $416(90)$ & $48(10)$ & $464(100)$ \\
Jiskairumoko & $77(89)$ & $11(11)$ & $88(100)$ \\
\hline
\end{tabular}

\section{Raw Materials}

Finally, the mobility and projectile technology sub-models anticipate trends in raw material properties. Declining mobility is expected to reduce access to non-local raw materials. Distinguishing local versus non-local materials in the Ilave Basin is, unfortunately, not straightforward. We have argued above that some portion of igneous materials must be non-local. Chert artifacts, in contrast, tend to be small and consistent with local acquisition from gravel deposits. We therefore predict that a decrease in mobility would be reflected in a decrease in the proportion of igneous artifacts in this special geologic circumstance. Consistent with this expectation, we find that the proportion of igneous artifacts decreases dramatically and significantly $\left(\chi^{2}=833, d f=1, p\right.$ $<0.01$ ) from $49 \%$ of the Soro Mik'aya Patjxa assemblage to $2 \%$ of the Jiskairumoko assemblage (Table 9). This pattern obtains whether considering tools or debitage. Although the differences in raw material emphasis are striking and the result is statistically robust, the linking argument is admittedly circuitous, leading us to consider the outcome weak support for the prediction of increasing emphasis on local materials.

A second prediction for raw material change is deduced from the projectile technology sub-model. The decrease in projectile point size anticipates increased use of smaller source materials. In the previous section, we argued that igneous artifacts tend to come from sources with larger source materials including primary geologic deposits compared to cherts, which tend to come almost exclusively from small river gravels. Thus, this prediction also anticipates a decline in igneous material proportions, which finds support in the test described in the previous paragraph. Again, given the admittedly circuitous rationale, we consider this result to be weak support for the prediction of decreasing preference for large source materials.

It is worth noting that Railey (2010) deduced a decrease in the frequency of fine grained materials as societies transition from dart to arrow production. The rationale is that larger bifaces require better materials, so demand for fine grained materials should decline as bifaces get smaller. We do not find this logic particularly compelling. Regardless of whether or not a flint knapper is making dart or arrow points, it seems that fine-grained materials will always be preferred, all other things being equal. We therefore omit this prediction from our research design. Nonetheless, we did examine our data for trends in raw material texture. While we indeed observe a dramatic shift in raw material preferences between Soro Mik'aya Patjxa and Jiskairumoko, the shift trends markedly in the opposite direction that Railey predicts. Reducing the material counts in Table 9 to course- versus fine-grained materials results in course:fine proportions of 66:34 for flakes and 76:24 for bifaces at Soro Mik'aya Patjxa (Table 10). These ratios drop precipitously and significantly to 2:98 for flakes $\left(\chi^{2}=\right.$ 435.9, $d f=1, p<0.01)$ and 1:99 for bifaces at Jiskairumoko $\left(\chi^{2}=156.9, d f=1, p<\right.$ 


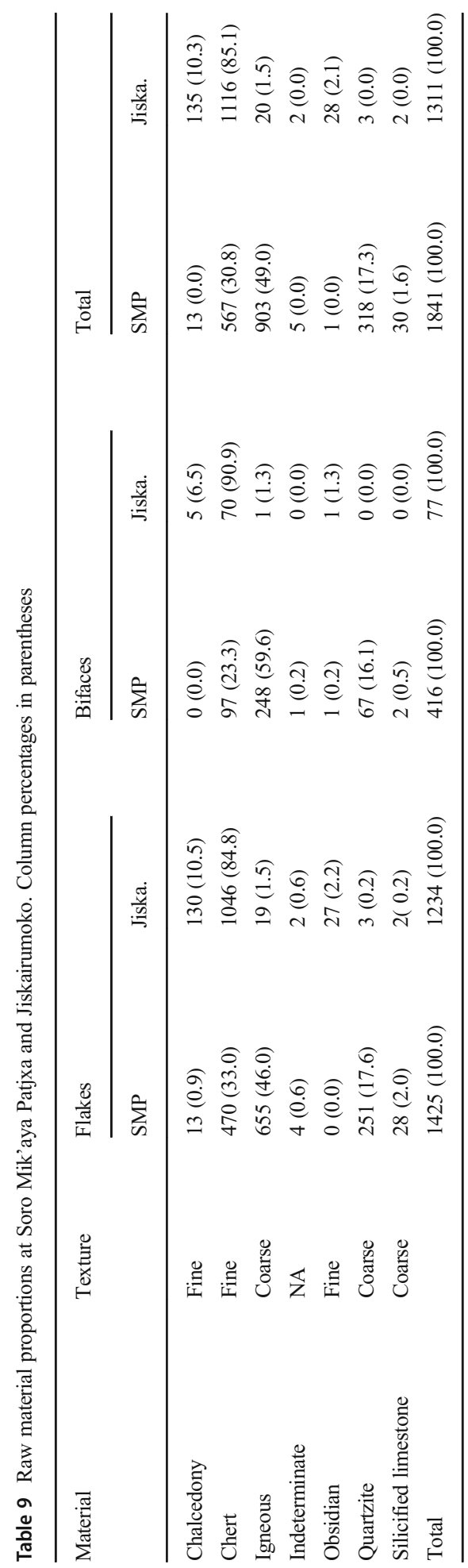


Table 10 Coarse- and fine-grained material counts at Soro Mik'aya Patjxa and Jiskairumoko. Counts exclude indeterminate specimens. Column percentages in parentheses

\begin{tabular}{|c|c|c|c|c|c|c|}
\hline \multirow[t]{2}{*}{ Material } & \multicolumn{2}{|l|}{ Flakes } & \multicolumn{2}{|l|}{ Bifaces } & \multicolumn{2}{|l|}{ Total } \\
\hline & SMP & Jiska. & SMP & Jiska. & SMP & Jiska. \\
\hline Coarse grain & $934(66)$ & $24(2)$ & $317(76)$ & $1(1)$ & $1251(68)$ & $100(8)$ \\
\hline Fine grain & $483(33)$ & $1203(98)$ & $98(24)$ & 76 (99) & $581(32)$ & $1204(92)$ \\
\hline Total & $1417(100)$ & $1227(100)$ & $415(100)$ & 77 (100) & $1832(100)$ & $1304(100)$ \\
\hline
\end{tabular}

0.01). It seems that the raw material patterns may be better understood as a result of material accessibility and size requirements than texture.

\section{Summary and Conclusion}

Previous archaeological evidence suggests that sometime in the Lake Titicaca Basin Terminal Archaic Period, 5.0-3.5 cal. ka, subsistence shifted from hunting and gathering to herding and farming, residential mobility declined giving rise incipient sedentism and weapon systems transitioned from atlatl to archery technology

Table 11 Behavioral change, predicted effects on lithics, and comparison to observed changes between Soro Mik'aya Patjxa and Jiskairumoko lithic assemblages

\begin{tabular}{|c|c|c|c|c|}
\hline \multicolumn{2}{|c|}{ Lithic variable } & \multicolumn{3}{|l|}{ Behavioral change } \\
\hline Class & Variable & Hunting $\rightarrow$ gathering & Mobile $\rightarrow$ sedentary & Atlatl $\rightarrow$ bow \\
\hline Core & Expedient & No effect & Increase & No effect \\
\hline Core & Bifacial & No effect & Decrease & No effect \\
\hline Flake & Mass & No effect & Increase & Decrease $^{* *}$ \\
\hline Flake & Area & No effect & No effect & Decrease $^{* *}$ \\
\hline Flake & Thickness & No effect & Increase & Decrease $e^{* *}$ \\
\hline Flake & Aspect ratio & No effect & Decrease & No effect \\
\hline Flake & Bending initiation & Decrease ${ }^{* *}$ & Decrease ${ }^{* *}$ & Decrease ${ }^{* *}$ \\
\hline Flake & Dorsal flake scars & Decrease & Decrease & Decrease \\
\hline Flake & Thickness:mass & Decrease $^{* *}$ & Decrease $^{* *}$ & Decrease $^{* *}$ \\
\hline Point & Width & No effect & No effect & Decrease $^{* *}$ \\
\hline Point & Thickness & No effect & No effect & Decrease* \\
\hline Point & Mass & No effect & No effect & Decrease $* *$ \\
\hline Point & Frequency & Decrease & No effect & No effect \\
\hline Material & Local (\% chert) & No effect & Increase* & No effect \\
\hline Material & Size (\% igneous) & No effect & No effect & Decrease* \\
\hline
\end{tabular}

Reject (in italics)

*Weak support

**Strong support 
(Aldenderfer, 1989; Bruno, 2006; Craig, 2012; Hastorf, 2008; Janusek, 2008; Stanish, 2003). We have examined these behavioral shifts through the lens of lithic technology. Table 11 summarizes the results of our examination of two assemblages. The balance shows that the transition from atlatl to archery technology overwhelmingly captures the most variation between the two lithic assemblages. Of the ten predictions for lithic structure, eight find strong support, one finds weak support, and one is rejected. Most notably, projectile point size was found to decrease significantly $(p<0.01)$ across empirically determined dart/arrow size boundaries. In addition, flake size decreased significantly $(p<0.01)$ along with the frequency of bifacial thinning flakes, and toolstone selection trended toward smaller raw materials.

The one prediction of the projectile technology sub-model that fails to find support is dorsal flake scar count, which is just one of three proxies for bifacial thinning flakes. We suspect that this test may conflict with trends in raw material variation. Namely, we suspect that the observed increase in dorsal flake scar counts may be an artifact of flake scar visibility, which may be lower on coarse-grained materials. Because coarse-grained materials are more abundant in the Soro Mik'aya Patjxa assemblage, dorsal flake scars may be under-counted. Regardless, the projectile technology thesis finds overwhelming support in the lithic assemblage leading us to conclude that the adoption of archery technology played a prominent role in cultural transformation following the Late Archaic Period, during the Terminal Archaic Period.

Having found that changes in projectile technology may have had a strong effect on the lithic assemblage, we now take stock of potential diet and mobility effects. We observed that the diet sub-model correctly predicts decreases in bifacial thinning flakes but that the data fail to meet the expectation of decreasing projectile point frequency. Because of the failure to predict decreasing projectile point frequency and because the expectations for bifacial thinning flakes can be explained more parsimoniously by the projectile technology submodel, we conclude that the data are most consistent with a behavioral interpretation in which hunting continued to play a prominent role in the Terminal Archaic Period.

Similarly, we find that the expectations for declining mobility are generally unmet. While the mobility model does correctly anticipate changes in the frequency of bifacial thinning flakes, again, the projectile technology sub-model more parsimoniously accounts for this variation. The mobility model accounts for expectations related to increasing use of local raw materials, which is indexed here by a declining proportion of igneous materials. But again, that prediction can be more parsimoniously accounted for by the projectile technology model, which predicts decreasing interest in large raw material sources, indexed by proportion of igneous artifacts. The other three predictions that are unique to the mobility model - a decrease in bifacial core frequency, an increase in expedient core frequency, and an increase in flake aspect ratio-fail to find support in the data. While there does seem to be a decrease in the formal:informal core ratios, the decrease is not statistically significant. We furthermore note that the low frequency of bifacial cores - only two in both assemblages - is consistent with a relatively low degree of residential mobility in both periods.

In the final analysis, it seems that a behavioral model in which the appearance of archery technology occurred during the Terminal Archaic Period alone offers the most parsimonious explanation for the observed trends in the lithic assemblages. By including changing subsistence or mobility patterns, little predictive power for lithic assemblage structure would seem to be gained. We conclude from the lithic evidence that (a) large mammal hunting was 
important in both periods with no detectable decline in importance, (b) residential mobility was relatively low in both periods with no detectable decline, and (c) archery technology was adopted sometime during the Terminal Archaic Period between 5.0 and $3.5 \mathrm{cal}$. ka. It is clear that diet and mobility ultimately changed dramatically in the Titicaca Basin, but the lithic evidence suggests that those shifts were small across the Late/Terminal Archaic Period boundary, with more dramatic diet and mobility changes likely to have occurred in the subsequent Formative Period.

\section{Discussion}

The Altiplano data examined here are most consistent with a behavioral model in which the adoption of archery technology on the Andean Altiplano drove changes in lithic industries beginning around $5.0 \mathrm{cal}$. ka. The finding more broadly supports a model in which archery technology was a major driver of noticeable changes in lithic industries throughout the Americas, particularly with respect to changing bifacial reduction strategies. Perhaps the most intriguing implications of this finding are that archery technology appeared surprisingly early in South America and played a crucial role in precipitating socioeconomic changes in the Titicaca Basin before major dietary shifts and sedentarization. While suggestive, we underscore that these implications are not conclusive. To advance this research, we suggest a few directions with regard to Altiplano archaeology and beyond.

\section{Future Directions for Lithic Analysis on the Andean Altiplano}

The Altiplano case study used in this analysis was ideal because the two lithic assemblages span a period thought to represent the transition to incipient sedentism, food production, and archery technology. The most parsimonious fit between the theory and data, we suggest, is found in the projectile technology sub-model, which suggests that the adoption of archery technology sometime between 5.0 and $3.5 \mathrm{cal}$. ka drove the observed differences in the lithic assemblages of Soro Mik'aya Patjxa and Jiskairumoko. However, it is important to emphasize that the introduction of archery technology before $3.5 \mathrm{cal}$. ka is not confirmed (Owen, 1998). Klink and Aldenderfer (2005) proposed a Terminal Archaic Period adoption based on qualitative perceptions of a size decrease in projectile points at that time in the South Central Andes. If it is the case that archery technology was in the Andes before $3.5 \mathrm{cal}$. ka, it would represent a remarkably early adoption for the Americas. North American adoption of the bow appears to have been relatively late, arguably in just the last 2000 years according to a recent conservative estimate (Bettinger, 2015). Others have suggested earlier North American adoptions as early as 4 cal ka or earlier (Blitz, 1988; Maschner \& Mason, 2013; Odell, 1988). An analysis of projectile point metrics from Brazil raises the remote possibility of an Early Holocene use of archery technology in South America (Okumura \& Araujo, 2015). Neither bows nor arrows have been securely identified or directly dated to the Terminal Archaic Period in the South Central Andes (Owen, 1998). Of course, direct observations and dates on atlatls are also lacking. The absence of evidence for early archery technology therefore cannot be taken as evidence of 
absence at this time. If direct evidence is to be found, it will likely be with continued exploration of rockshelter sites and dry coastal contexts.

Another limitation of the current analysis in terms of inferring the arrival of the bow and arrow on the Altiplano is the small sample size. We investigated just two projectile point assemblages from two sites. Although we observe a decrease in projectile point size, it is unclear how pervasive the pattern is or how projectile point size varies across other time periods. Our working model would suggest that all projectile point forms prior to the Terminal Archaic Period are large dart forms, and all point forms in subsequent periods are arrow or dart forms. Additional work is needed to contextualize the pattern at broader geographic and temporal scales.

That we have not observed strong signals in diet and mobility indicators suggests that those behaviors changed relatively little between the Late and Terminal Archaic periods. In fact, the paucity of bifacial cores and apparent focus on what appears to be largely local materials seem to indicate a relative degree of residential sedentism, or at least restricted territories, during both time periods. This observation is consistent with arguments made by Rick (1980), who suggested early sedentism due to high-density camelid resources. Similarly, Aldenderfer (1998) argued that the hypoxic highelevation environment ought to induce relatively restricted mobility early on. Haas and Viviano Llave (2015) proposed that the inhabitants of Soro Mik'aya Patjxa may have been relatively territorial based on the presence of high violent trauma rates and artificial cranial modification, which may have signaled territoriality.

Yet, those observations seem at odds with other lines of evidence that suggest increasing sedentism between Soro Mik'aya Patjxa and Jiskairumoko. Namely, the appearance of ceramics, incipient agriculture, and semi-subterranean house structures at Jiskairumoko would all seem to indicate changing diet and sedentarization. But as we noted in the introduction, those lines of evidence are relatively weak given that ceramics are rare at Jiskairumoko, mobile populations occasionally produce ceramics, horticulturalists can be quite mobile, and the form of Late Archaic houses in the Titicaca Basin remains relatively unknown, precluding comparison with the Terminal Archaic houses. The sum of evidence would therefore seem to favor a relatively high and constant degree of residential sedentism, or at least territoriality, across the Late-Terminal Archaic periods. Stable isotope chemistry analysis of human skeletal remains, which have been recovered from both sites (Craig, 2012; Haas \& Viviano Llave, 2015), would perhaps be the most productive avenue for assessing the extent to which mobility changed between the Late and Terminal Archaic periods on the Altiplano.

\section{Comparison with Asana}

How do the Altiplano results presented here compare to similar studies? We do not attempt a broad review here, but instead focus first on a comparison with a related study in the South Central Andes and second on a comparison with the two North American lithic studies that informed our model. The South American case that we cross reference is Aldenderfer's (2006) model of emergent pastoral economies in the adjacent Rio Asana drainage, west of the Lake Titicaca Basin.

Drawing insights from human behavioral ecology, archaeology, ethnography, and experimental foraging, Aldenderfer proposed that the evolution of camelid herding 
occurred at the intersection of optimal foraging, sexual division of labor, and costly signaling. In this model, residentially sedentary foraging populations of the Qhuna Phase (5.7-4.9 cal. ka) foraged chenopods and hunted taruca and guanaco. Because discount rates on hunting large mammals are high - it is costly to forgo taking an animal on encounter, herding was a virtual impossibility in the Qhuna phase. However, in the subsequent Awati phase (4.9-2.7 cal. ka), some combination of over-hunting and human population crash lowered the discount rates, though to a rate that would still have been insufficient to justify "conserving" animals. What may have finally tipped the balance was the male quest for status and prestige. From this vantage, the costliness of passing up large mammal kills, protecting those mammals, and growing the herd made such behavior an honest signal of male worth, garnering leverage in some combination of alliance formation and mate choice. Meanwhile, females continued to invest in Chenopodium harvest, which is the more reliable subsistence resource for provisioning offspring. Importantly, this process ensued during the Awati Phase of the Rio Asana drainage, which coincides with the Terminal Archaic Period of the Titicaca Basin.

Aldenderfer's evolutionary ecology model accords well with the inferred introduction of archery technology described in the current analysis. Like Aldenderfer's model, archery is theoretically linked to resource privatization and sexual division of labor. Bettinger (2013) argues that the introduction of the archery in western North America was part-and-parcel to plant-food intensification and territoriality. In this view, archery catalyzed the use and privatization of oak and piñon tree patches by making those resources more defensible. The bow furthermore freed hunter-gatherers from the burden of demand sharing, which would have been necessary when economies emphasized atlatl hunting (Bettinger, 2015). This is because atlatl hunting is risky relative to foraging and archery hunting. Economies that relied heavily on atlatl hunting required high degrees of sharing to offset risks. The bow-and-arrow, in contrast, goes hand-inhand with resource privatization, precisely what Aldenderfer envisions for the Awati Phase in the Asana region.

In addition, the use of archery technology likely exacerbates sexual division of labor. Grund (2017) observed that females and males were likely to have been equally skilled in atlatl use because peak proficiency in learning the atlatl can be achieved before females reach reproductive age when considerable time must be allocated to childcare. In contrast, archery takes longer to learn. While female training is stymied by pregnancy and child care, young males continue to enhance their skill, putting females at a disadvantage when it comes to developing hunting skill.

The idea that atlatls were a relatively equal-opportunity technology finds support in a recent analysis of early forager burial practices in the Americas. Haas et al. (2020) observed a young adult female individual interred with a big-game hunting toolkit approximately 9000 years ago at the site of Wilamaya Patjxa, approximately $1 \mathrm{~km}$ from Soro Mik'aya Patjxa. That analysis further identifies this mortuary practice to have been widespread throughout Americas, at least prior to $8 \mathrm{cal}$. ka, several millennia before the appearance of archery technology. A meta-analysis reveals that nearly half of early human burials associated with big-game hunting tools have been identified as female individuals. Such observations are consistent with relatively undifferentiated labor practice among atlatl hunters. Thus, the appearance of the bow-and-arrow during 
the Terminal Archaic Period is consistent with Aldenderfer's proposition of increasing sexual division of labor at that time.

In sum, the interpretation of technological change between Soro Mik'aya Patjxa and Jiskairumoko aligns with Aldenderfer's model of perceived gendered labor, costly signaling, and incipient camelid management in the Terminal Archaic Period. It may well be that archery further contributed to lowering the discount rates of hunting - and possibly gathering - in ways that catalyzed the privatization of animal and plant resources. We suggest only one minor amendment to the model as applied to the Titicaca Basin. Rather than Chenopodium having been the focus of female labor, current evidence suggests that tubers-likely Solanum sp.--were the major plantresource at play in the Titicaca Basin as indicated by ubiquitous parenchyma fragments in the paleoethnobotanical assemblage at Soro Mik'aya Patjxa (Haas \& Viviano Llave, 2015), dental wear patterns suggestive of tuber processing among human burials at Soro Mik'aya Patjxa (Watson \& Haas, 2017), and Solanum sp. starch grains at Jiskairumoko (Rumold \& Aldenderfer, 2016). This detail nevertheless does not change the basic mechanics of the model.

\section{Comparison with North America}

In North America, we can compare the current study with comparable lithic analyses that have investigated relationships among diet, mobility, technology, and lithics. Unfortunately, but understandably, not all studies record lithic variables the same way making comparison difficult. Moreover, broad comparison is not the goal of this analysis. We therefore focus our North American comparisons on the two studies that informed our working model - those of Parry and Kelly (1987) and Railey (2010). Parry and Kelly examined data from five North American case studies including one from the Plains, three from the US Southwest, and one from Mesoamerica. In addition, Railey examined a case study from the US Southwest (Rio Hondo). We key in on two variables that Parry and Kelly emphasized-biface:core proportions and bifacial thinning flake proportions. To compare these trends across regions, we rely on the widely used chronological scheme in archaeology, which envisions Archaic through Formative periods (Willey \& Phillips, 1958). We center the data on the periods that may be thought of as transitional periods (Fig. 6). On the Altiplano, this transitional period is the Terminal Archaic Period. In the US Southwest, it is the Basketmaker Period.

Figure 6 shows relatively consistent trends. In the Archaic periods, biface and bifacial thinning flake frequencies are high. In the Formative periods, they are low. In all cases, the transitional periods roughly coincide with increasing cultivation, reduced mobility, and the appearance of archery technology. It seems likely that all these behavioral changes were at play in all of the regions under consideration. However, our analysis, as with that of Railey's (2010), suggests that the major factor affecting lithic assemblages during these transitional periods was the introduction of archery technology.

Additional analysis of archaeological lithic assemblages is needed. The diachronic North American case studies that Parry and Kelly considered have not, to our knowledge, been subjected to analysis for predicted changes in projectile point size. Another limitation of current empirical work is its North American bias. Six of the seven case studies shown in Fig. 6 are North American case studies. This geographic bias is problematic given that geographically and temporally proximate technological 

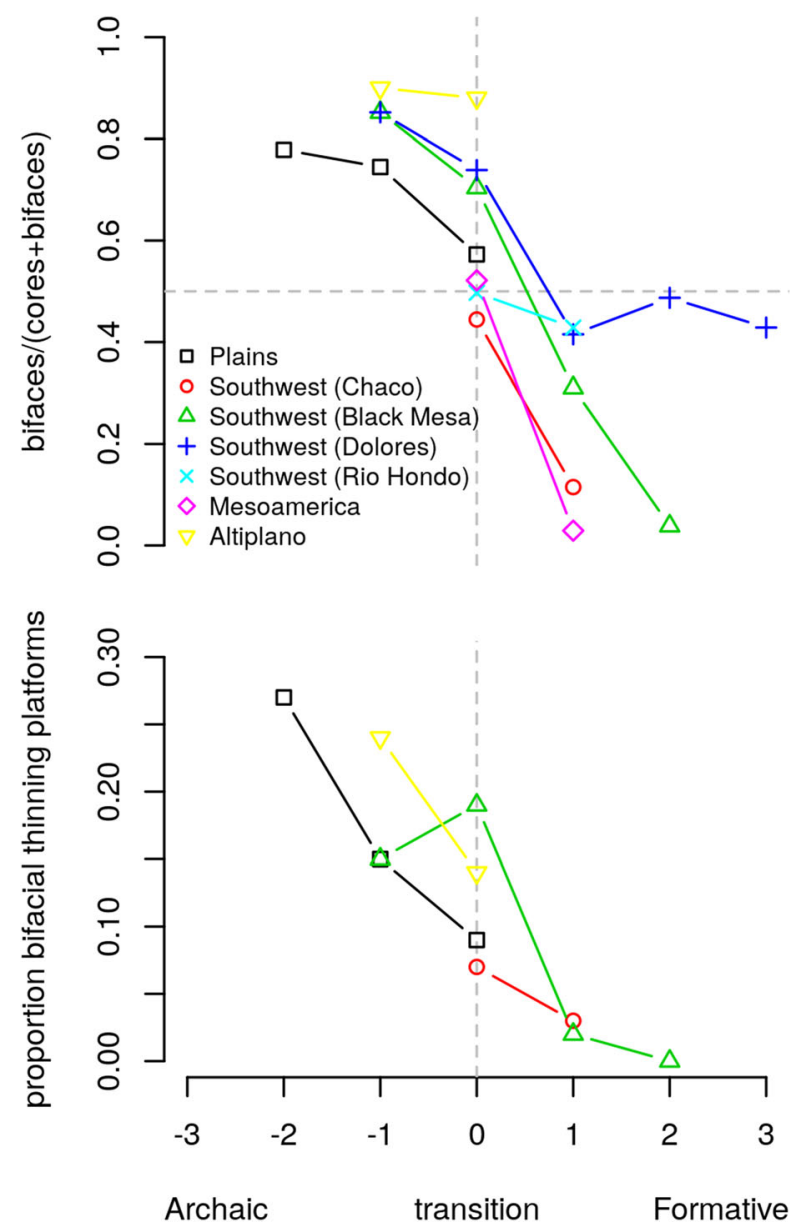

Fig. 6 Comparison of lithic data across archaeological periods in North America, Mesoamerica, and on the Altiplano. The $\mathrm{X}$-axis represents archaeological time periods with 0 marking transitional period, positive numbers trending sequentially toward Formative periods and negative numbers trending sequentially toward Archaic periods. In all cases, biface:core ratios (top) and bifacial thinning flake frequencies (bottom) decline over time. Data from Parry and Kelly (1987) and Railey (2010)

traditions tend to have shared cultural histories that cannot be assumed to reflect independent cultural phenomena-an analytical dilemma known as Galton's Problem or spatial auto-correlation (Murdock \& White, 1969). Although Parry and Kelly evaluated five archaeological cases, three were from the US Southwest and thus were likely to have shared close cultural lineages. Railey's case study is a single US Southwest case and thus does not solve the cultural independence problem. Even the other two regional populations examined by Parry and Kelly - the Great Plains and Mesoamerica - are well known to have interacted or shared heritage with populations in the US Southwest. Odell (1998) extended the analysis beyond these culturally adjacent traditions finding agreement with the mobility model in lithic assemblages of the Illinois River Valley. Nonetheless, Odell's case is yet another North American case. 
While complete cultural independence is ultimately impossible given the deep cultural roots of humanity, testing model predictions in diverse times and places and at multiple geographic scales presents one solution to examining cultural transmission effects. Our Altiplano case represents a small step in that direction. Additional systematic comparison is needed with other South American assemblages as well as assemblages from other continents outside of North America. Particularly important in expanding the geographic scope of this research will be case studies where archery was decidedly never adopted such as in Australia and Oceania.

\section{Other Lines of Evidence}

Integration with independent lines of evidence for subsistence and mobility practices is lacking. Many of our assumptions about subsistence and mobility are based on proxy data, some stronger than others. More direct evidence of individual human diets and mobility is occasionally available in the form of human bone isotope chemistry (Chala-Aldana et al., 2017; Eerkens et al., 2014). Stable carbon, nitrogen, and strontium isotopes can provide clear evidence of dietary behaviors often at multiple stages in individuals lives. In particular, changes in trophic levels can be observed, which would be invaluable for determining dietary shift related to increasing plant use. Stable strontium, oxygen, and carbon isotopes can provide reliable insights into mobility patterns. Again, such data would be invaluable for establishing mobility patterns as independent variables when examining the effects of changing mobility on lithic assemblage structure.

Another important line of research will be experimental analysis of the performance characteristics of projectile points of different size. The dart/arrow point size thresholds that form a critical component in this and other studies remain an empirical premise. We wish to know, what are the economic trade-offs between atlatls, bows, small points, and large points? In other words, what exactly is lost when one tips an atlatl dart with a small point? What about when one tips an arrow with a large point?

Some studies offer some preliminary insights. Couch et al. (1999) found that projectile point size does not affect throw distance. Mika et al. (2020) found that smaller points have greater penetration power. Of course, such studies alone lead us to wonder why point size should consistently vary between darts and arrows. They fundamentally cannot account for the observed modalities in projectile point size between dart and arrow points. Christenson (1986) offered a wealth of hypotheses still in need of investigation. What is currently lacking then is research that systematically fills in gaps and integrates previous work to understand what may be driving the empirical trends in projectile point size and the extent to which we should expect those trends to apply cross-culturally.

We began this analysis with the observation that the Titicaca Basin Terminal Archaic Period, 5.0-3.5 cal. ka, represents a period of socioeconomic transformation in which forager economies gave way to agropastoral economies, populations became residentially sedentary, and archery technology appeared alongside the atlatl. We evaluated these hypothesized changes from the perspective of lithic technology, first synthesizing a model linking lithic assemblage structure to changes in diet, mobility, and projectile technology. We then confronted the model predictions with lithic data from two archaeological sites spanning the Late/Terminal Archaic boundary. We found that the strongest signal in the lithic data was anticipated by the projectile technology 
sub-model. Signals of widening diet breadth and sedentarization were not observed in the lithic data, suggesting that those processes likely accelerated later, potentially at the end of the Terminal Archaic Period or in the subsequent Formative Period. These results suggest a surprisingly early but unconfirmed adoption of archery technology in South America. To the extent that archery was present in the Terminal Archaic Period, it may have precipitated major socioeconomic shifts, creating a context for resource privatization, sedentism, and domestication in the high Andes.

Supplementary Information The online version contains supplementary material available at https:/doi.org/ 10.1007/s10816-021-09525-7.

Acknowledgements Luis Flores (UC Davis) assisted with the projectile point graphic and provided helpful feedback on a draft of this manuscript. Nicolas Zwyns (UC Davis), Tamara Dogandžić (Max Plank), and Kevin Smith (UC Davis) directed us to key references and concepts in lithic analysis. Three anonymous reviewers provided feedback that greatly improved the paper.

Code Availability Not applicable.

Author Contribution $\mathrm{RH}$ and NK designed the analysis. RH and MA excavated the materials. NK collected the lithic data. RH and NK wrote the manuscript. MA edited the manuscript.

Funding National Science Foundation (BCS-1311626 awarded to RH and SBR-9816313 awarded to MA), the American Philosophical Society (Lewis and Clark grant awarded to RH), and the University of Arizona, and University of California, Davis.

Data Availability All relevant data are provided in the manuscript or Electronic Supplementary Materials, which contain raw lithic data.

\section{Declarations}

Conflict of Interest The authors declare no competing interests.

Supplementary Information The online version contains supplementary material available at https://doi.org/ 10.1007/s10816-021-09525-7.

Open Access This article is licensed under a Creative Commons Attribution 4.0 International License, which permits use, sharing, adaptation, distribution and reproduction in any medium or format, as long as you give appropriate credit to the original author(s) and the source, provide a link to the Creative Commons licence, and indicate if changes were made. The images or other third party material in this article are included in the article's Creative Commons licence, unless indicated otherwise in a credit line to the material. If material is not included in the article's Creative Commons licence and your intended use is not permitted by statutory regulation or exceeds the permitted use, you will need to obtain permission directly from the copyright holder. To view a copy of this licence, visit http://creativecommons.org/licenses/by/4.0/. 


\section{References}

Aldenderfer, M. S. (1989). The Archaic Period in the south-central Andes. Journal of World Prehistory, 3(2), 117-158. https://doi.org/10.1007/bf00975759.

Aldenderfer, M. S. (1998). Montane Foragers. University of Iowa Press. https://doi.org/10.2307/j. ctt20q1wq5.

Aldenderfer, M. S. (2006). Costly signaling, the sexual division of labor, and animal domestication in the Andean highlands. In D. J. Kennett \& B. Winterhalder (Eds.), Behavioral ecology and the transition to agriculture (pp. 167-196). University of California Press. https://doi.org/10.1525/9780520932456-011.

Aldenderfer, M. S., \& Flores Blanco, L. A. (2011). Reflexiones para avanzar en los estudios del Periodo Arcaico en los Andes Centro-Sur. Chungara: Revista de Antropología Chilena, 43(especial), 531-550. https://doi.org/10.4067/S0717-73562011000300011.

Aldenderfer, M., Craig, N. M., Speakman, R. J., \& Popelka-Filcoff, R. (2008). Four-thousand-year-old gold artifacts from the Lake Titicaca Basin, southern Peru. Proceedings of the National Academy of Sciences, 105, 5002-5005. https://doi.org/10.1073/pnas.0710937105.

Amick, D. S., Mauldin, R. P., \& Tomka, S. A. (1988). An evaluation of debitage produced by experimental bifacial core reduction of a Georgetown chert nodule. Lithic Technology, 17(1), 26-36. https://doi.org/10. 1080/01977261.1988.11754523.

Andrefsky, W. J. (2005). Lithics: macroscopic approaches to analysis. Cambridge University Press. https:// doi.org/10.1017/cbo9780511810244.

Bettinger, R. L. (2013). Effects of the bow on social organization in western North America. Evolutionary Anthropology: Issues, News, and Reviews, 22(3), 118-123. https://doi.org/10.1002/evan.21348.

Bettinger, R.L., (2015). Orderly Anarchy: Sociopolitical Evolution in Aboriginal California. University of California Press

Blitz, J. H. (1988). Adoption of the bow in prehistoric North America. North American Archaeologist, 9(2), 123-145. https://doi.org/10.2190/hn64-p1ud-nm0a-j0lr.

Bruno, M. C. (2006). A morphological approach to documenting the domestication of chenopodium in the Andes. In M. A. Zeder, D. G. Bradley, E. Emshwiller, \& B. D. Smith (Eds.), Documenting domestication: New genetic and archaeological paradigms (pp. 32-45). University of California Press.

Buchanan, B., Mraz, V., \& Eren, M. I. (2016). On identifying stone tool production techniques: An experimental and statistical assessment of pressure versus soft hammer percussion flake form. American Antiquity, 81(4), 737-751. https://doi.org/10.1017/s0002731600101064.

Chala-Aldana, D., Bocherens, H., Miller, C., Moore, K., Hodgins, G., \& Rademaker, K. (2017). Investigating mobility and highland occupation strategies during the Early Holocene at the Cuncaicha rock shelter through strontium and oxygen isotopes. Journal of Archaeological Science: Reports, 19, 811-827. https:// doi.org/10.1016/j.jasrep.2017.10.023.

Christenson, A. L. (1986). Projectile point size and projectile aerodynamics: An exploratory study. Plains Anthropologist, 31(112), 109-128. https://doi.org/10.1080/2052546.1986.11909324.

Cipolla, L. M. (2005). Preceramic Period settlement patterns in the Huancané-Putina River Valley, Northern Titicaca Basin, Peru. In C. Stanish, A. B. Cohen, \& M. S. Aldenderfer (Eds.), Advances in Titicaca Basin Archaeology-1 (pp. 55-64) Cotsen Institute of Archaeology at UCLA.

Collins, M.B., (2002). Clovis blade technology. University of Texas Press

Couch, J. S., Stropes, T. A., \& Schroth, A. B. (1999). The effect of projectile point size on atlatl dart efficiency. Lithic Technology, 24(1), 27-37. https://doi.org/10.1080/01977261.1999.11720943.

Craig, N. M. (2011). Cultural dynamics, climate, and landscape in the south-central Andes during the mid-late Holocene: A consideration of two socio-natural perspectives. Chungará, 43(especial), 367-391. https:// doi.org/10.4067/s0717-73562011000300004.

Craig, N. M. (2012). Transiciones del Arcaico Tardío al Formative Temprano: una perspectiva desde la arqueología de la unidad doméstica de dos sitios del Valle del Río Ilave, Cuenca del Lago Titicaca. In L. Flores Blanco \& H. Tantaleán (Eds.), Arqueología de la Cuenca del Titicaca, Perú (pp. 41-130). Cotsen Istitute of Archaeology at UCLA: Instituto Francés de Estudios Andinos.

Danielson, J. J., \& Gesch, D. B. (2011). Global multi-resolution terrain elevation data 2010 (GMTED2010). In United States Geological Survey Open-File Report 2011-1073. Washington: D.C.

Eerkens, J. W. (2003). Residential mobility and pottery use in the western Great Basin. Current Anthropology, 44(5), 728-738. https://doi.org/10.1086/379262.

Eerkens, J. W., Barfod, G. H., Jorgenson, G. A., \& Peske, C. (2014). Tracing the mobility of individuals using stable isotope signatures in biological tissues: "locals" and "non-locals" in an ancient case of violent death 
from Central California. Journal of Archaeological Science, 41, 474-481. https://doi.org/10.1016/j.jas. 2013.09.014.

Fogelin, L. (2007). Inference to the best explanation: A common and effective form of archaeological reasoning. American Antiquity, 72(4), 603-626. https://doi.org/10.2307/25470436.

Grund, B. S. (2017). Behavioral ecology, technology, and the organization of labor: How a shift from spear thrower to self bow exacerbates social disparities. American Anthropologist, 119(1), 104-119. https://doi. org/10.1111/aman.12820.

Haas, R., \& Viviano Llave, C. (2015). Hunter-gatherers on the eve of agriculture: Investigations at Soro Mik'aya Patjxa, Lake Titicaca Basin, Peru, 8000-6700 BP. Antiquity, 89, 1297-1312. https://doi.org/10. 15184/aqy.2015.100.

Haas, R., Klink, C. J., Maggard, G. J., \& Aldenderfer, M. S. (2015). Settlement-size scaling among prehistoric hunter-gatherer settlement systems in the New World. PLOS ONE, 10(11), e0140127. https://doi.org/10. 1371/journal.pone.0140127.

Haas, R., Stefanescu, I. C., Garcia-Putnam, A., Aldenderfer, M. S., Clementz, M. T., Murphy, M. S., Viviano Llave, C., \& Watson, J. T. (2017). Humans permanently occupied the Andean highlands by at least $7 \mathrm{ka}$. Royal Society Open Science, 4(6), 170331. https://doi.org/10.1098/rsos.170331.

Haas, R., Watson, J., Buonasera, T., Southon, J., Chen, J. C., Noe, S., Smith, K., Llave, C. V., Eerkens, J., \& Parker, G. (2020). Female hunters of the early Americas. Science Advances, 6, eabd0310. https://doi.org/ 10.1126/sciadv.abd0310.

Haslett, J., \& Parnell, A. C. (2008). A simple monotone process with application to radiocarbon-dated depth chronologies. Journal of the Royal Statistical Society: Series C (Applied Statistics), 57(4), 399-418. https://doi.org/10.1111/j.1467-9876.2008.00623.x.

Hastorf, C. A. (2008). The Formative Period in the Titicaca Basin. In H. Silverman \& W. H. Isbell (Eds.), Handbook of South American archaeology (pp. 545-561). Springer. https://doi.org/10.1007/978-0-38774907-5 28 .

Hildebrandt, W. R., \& King, J. H. (2012). Distinguishing between darts and arrows in the archaeological record: implications for technological change in the American West. American Antiquity, 77(4), 789-799. https://doi.org/10.7183/0002-7316.77.4.789.

Hogg, A. G., Heaton, T. J., Hua, Q., Palmer, J. G., Turney, C. S. M., Southon, J., Bayliss, A., Blackwell, P. G., Boswijk, G., Ramsey, C. B., Pearson, C., Petchey, F., Reimer, P., Reimer, R., \& Wacker, L. (2020). SHCal20 southern hemisphere calibration, 0-55,000 years cal BP. Radiocarbon, 62(4), 759-778. https:// doi.org/10.1017/rdc.2020.59.

Hughes, R. (2011). Obsidian in the Carson Desert: mobility or trade? University of Utah Press.

Janusek, J. W. (2004). Tiwanaku and its precursors: Recent research and emerging perspectives. Journal of Archaeological Research, 12(2), 121-183.

Janusek, J. W. (2008). Ancient Tiwanaku. Cambridge University Press.

Kelly, R. L. (1988). The three sides of a biface. American Antiquity, 53(4), 717-734. https://doi.org/10.2307/ 281115

Kelly, R. L. (2013). The lifeways of hunter-gatherers: The foraging spectrum. Cambridge University Press. https://doi.org/10.1017/CBO9781139176132.

Klink, C. J. (2005). Archaic Period research in the Río Huenque Valley, Peru. In C. Stanish, A. B. Cohen, \& M. S. Aldenderfer (Eds.), Advances in Titicaca Basin archaeology-1 (pp. 13-24) Cotsen Institute of Archaeology at UCLA.

Klink, C. J., \& Aldenderfer, M. S. (2005). A projectile point chronology for the South-Central Andean highlands. In C. Stanish, A. B. Cohen, \& M. S. Aldenderfer (Eds.), Advances in Titicaca Basin archaeology-1 (pp. 25-54) Cotsen Institute of Archaeology at UCLA.

Kuhn, S. L. (1994). A formal approach to the design and assembly of mobile toolkits. American Antiquity, 59(3), 426-442. https://doi.org/10.2307/282456.

Maschner, H., \& Mason, O. K. (2013). The bow and arrow in northern North America. Evolutionary Anthropology: Issues, News, and Reviews, 22(3), 133-138. https://doi.org/10.1002/evan.21357.

McCall, G. S. (2012). Ethnoarchaeology and the organization of lithic technology. Journal of Archaeological Research, 20(2), 157-203. https://doi.org/10.1007/s10814-011-9056-z.

McCall, G. S., Horowitz, R. A., \& Healan, D. (2019). Chert at Chalcatzingo: Implications of knapping strategies and technological organization for Formative economics. In R. A. Horowitz \& G. S. McCall (Eds.), Lithic technologies in sedentary societies (pp. 164-183). University Press of Colorado. https://doi. org/10.5876/9781607328926.

McElreath, R., (2016). Statistical rethinking: A Bayesian course with examples in $R$ and Stan. CRC Press/ Taylor \& Francis Group 
Mika, A., Flood, K., Norris, J. D., Wilson, M., Key, A., Buchanan, B., Redmond, B., Pargeter, J., Bebber, M. R., \& Eren, M. I. (2020). Miniaturization optimized weapon killing power during the social stress of late pre-contact North America (AD 600-1600). PLOS ONE, 15(3), e0230348. https://doi.org/10.1371/ journal.pone.0230348.

Murdock, G. P., \& White, D. R. (1969). Standard cross-cultural sample. Ethnology, 8(4), 329-369.

Odell, G. H. (1988). Addressing prehistoric hunting practices through stone tool analysis. American Anthropologist, 90(2), 335-356. https://doi.org/10.1525/aa.1988.90.2.02a00060.

Odell, G. H. (1998). Investigating correlates of sedentism and domestication in prehistoric North America. American Antiquity, 63(4), 553-571. https://doi.org/10.2307/2694108.

Okumura, M., \& Araujo, A. G. M. (2015). Contributions to the dart versus arrow debate: new data from Holocene projectile points from southeastern and southern Brazil. Anais da Academia Brasileira de Ciências, 87(4), 2349-2373. https://doi.org/10.1590/0001-3765201520140625.

Ostahowski, B., \& Kelly, R. L. (2014). Alm Rockshelter lithic debitage analysis: Implications for huntergatherer mobility strategies in the Big Horn Mountains, Wyoming. In D. H. MacDonald, J. William Andrefsky, \& P.-L. Yu (Eds.), Lithics in the West: Using lithic analysis to solve archaeological problems in western North America (pp. 120-141). The University of Montana Press.

Owen, B. (1998). Bows and spearthrowers in southern Peru and northern Chile evidence, dating, and why it matters. Paper presented at the 63rd Annual Meeting of the Society for American Archaeology, Seattle

Parry, W. J., \& Kelly, R. L. (1987). Expedient core technology and sedentism. In J. K. Johnson \& C. A. Morrow (Eds.), The organization of core technology and sedentism (pp. 285-304). West View Press.

Prasciunas, M. M. (2007). Bifacial cores and flake production efficiency: An experimental test of technological assumptions. American Antiquity, 72(2), 334-348. https://doi.org/10.2307/40035817.

Railey, J. A. (2010). Reduced mobility or the bow and arrow? Another look at "expedient" technologies and sedentism. American Antiquity, 75(2), 259-286. https://doi.org/10.7183/0002-7316.75.2.259.

Richerson, P. J., Boyd, R., \& Bettinger, R. L. (2001). Was agriculture impossible during the Pleistocene but mandatory during the Holocene? A climate change hypothesis. American Antiquity, 66(3), 387-411. https://doi.org/10.2307/2694241.

Rick, J.W., (1980). Prehistoric hunters of the high Andes. Academic Press

Rosenberg, M. (1998). Cheating at musical chairs. Current Anthropology, 39(5), 653-681. https://doi.org/10. $1086 / 204787$.

Rumold, C. U., \& Aldenderfer, M. S. (2016). Late Archaic-Early Formative Period microbotanical evidence for potato at Jiskairumoko in the Titicaca Basin of southern Peru. Proceedings of the National Academy of Sciences, 113, 13672-13677. https://doi.org/10.1073/pnas.1604265113.

Schenk, C.J., Viger, R.J. \& Anderson, C.P. (1999). South America geologic pap (geo6ag). United States Geological Survey Open-File Report 97-470-D, Denver

Shott, M. J. (1997). Stones and shafts redux: The metric discrimination of chipped-stone dart and arrow points. American Antiquity, 62(1), 86-101. https://doi.org/10.2307/282380.

Smith, B. D. (2001). Low-level food production. Journal of Archaeological Research, 9(1), 1-43. https://doi. org/10.1023/a:1009436110049.

Stanish, C. (2003). Ancient Titicaca: The evolution of complex society in southern Peru and northern Bolivia. University of California Press.

Stiner, M. C. (2001). Thirty years on the "broad spectrum revolution" and Paleolithic demography. Proceedings of the National Academy of Sciences, 98, 6993-6996. https://doi.org/10.1073/pnas. 121176198.

Thomas, D. H. (1978). Arrowheads and atlatl darts: how the stones got the shaft. American Antiquity, 43(3), 461-472. https://doi.org/10.2307/279405.

Watson, J. T., \& Haas, R. (2017). Dental evidence for wild tuber processing among Titicaca Basin foragers 7000 ybp. American Journal of Physical Anthropology, 164(1), 117-130. https://doi.org/10.1002/ajpa. 23261.

Whittaker, J., (1994). Flintknapping: Making and understanding stone tools. University of Texas Press

Willey, G. \& Phillips, P., (1958). Method and theory in American archaeology. University of Chicago Press

Publisher's Note Springer Nature remains neutral with regard to jurisdictional claims in published maps and institutional affiliations. 